\title{
Mutually Isomeric 2- and 4-(3-Nitro-1,2,4-triazol-1- yl)pyrimidines Inspired by an Antimycobacterial Screening Hit: Synthesis and Biological Activity against the ESKAPE Panel of Pathogens
}

\author{
Sergey Chuprun ${ }^{1}{ }^{\oplus}$, Dmitry Dar'in ${ }^{1}{ }^{(}$, Elizaveta Rogacheva ${ }^{2}$, Liudmila Kraeva ${ }^{2}$, Oleg Levin ${ }^{1}(\mathbb{D}$, \\ Olga Manicheva ${ }^{3}$, Marine Dogonadze ${ }^{3}$, Tatiana Vinogradova ${ }^{3}$, Olga Bakulina ${ }^{1}$ and \\ Mikhail Krasavin 1,4,*(D) \\ 1 Institute of Chemistry, Saint Petersburg State University, 199034 Saint Petersburg, Russia; \\ sergej.chuprun@mail.ru (S.C.); d.dariin@spbu.ru (D.D.); o.levin@spbu.ru (O.L.); o.bakulina@spbu.ru (O.B.) \\ 2 Pasteur Institute of Epidemiology and Microbiology, 14 Mira Street, 197101 Saint Petersburg, Russia; \\ elizvla@yandex.ru (E.R.); lykraeva@yandex.ru (L.K.) \\ 3 Saint Petersburg Research Institute of Phthisiopulmonology, 2-4 Ligovsky Prospekt, 191036 Saint Petersburg, \\ Russia; olgamanicheva@rambler.ru (O.M.); marine-md@mail.ru (M.D.); vinogradova@spbniif.ru (T.V.) \\ 4 Institute of Living Systems, Immanuel Kant Baltic Federal University, 236016 Kaliningrad, Russia \\ * Correspondence: m.krasavin@spbu.ru; Tel.: +7-931-3617-872; Fax: +7-812-428-6939
}

Received: 6 September 2020; Accepted: 30 September 2020; Published: 1 October 2020

check for updates

\begin{abstract}
Starting from the structure of antimycobacterial screening hit OTB-021 which was devoid of activity against ESKAPE pathogens, we designed, synthesized and tested two mutually isomeric series of novel simplified analogs, 2- and 4-(3-nitro-1,2,4-triazol-1-yl)pyrimidines, bearing various amino side chains. These compounds demonstrated a reverse bioactivity profile being inactive against $M$. tuberculosis while inhibiting the growth of all ESKAPE pathogens (with variable potency patterns) except for Gram-negative P. aeruginosa. Reduction potentials $\left(\mathrm{E}_{1 / 2}, \mathrm{~V}\right)$ measured for selected compounds by cyclic voltammetry were tightly grouped in the $-1.3--1.1 \mathrm{~V}$ range for a reversible single-electron reduction. No apparent correlation between the $\mathrm{E}_{1 / 2}$ values and the ESKAPE minimum inhibitory concentrations was established, suggesting possible significance of other factors, besides the compounds' reduction potential, which determine the observed antibacterial activity. Generally, more negative $\mathrm{E}_{1 / 2}$ values were displayed by 2-(3-nitro-1,2,4-triazol-1-yl)pyrimidines, which is in line with the frequently observed activity loss on moving the 3-nitro-1,2,4-triazol-1-yl moiety from position 4 to position 2 of the pyrimidine nucleus.
\end{abstract}

Keywords: bioreducible prodrugs; nitroazoles; 3-nitro-1,2,4-triazole; nucleophilic aromatic substitution; antimycobacterial activity; ESKAPE pathogens; cyclic voltammetry; reversible single-electron reduction

\section{Introduction}

$N$-Aryl-C-nitroazoles represent a general class of heterocyclic compounds which have found utility as pesticides [1], herbicides, fungicides [2] and high-energy materials [3-5]. At the same time, compounds belonging to this broadly defined chemical class are noticeably underrepresented in the medicinal chemistry literature [6]. Possible reasons for this include the negative stigma associated with nitro heteroaromatic moieties in general which are redox-active moieties and can therefore exert non-specific toxicity and mutagenicity [7]. Although nowadays such moieties continue being avoided, there is a steadily growing sentiment (particularly in the antibacterial field [8-10]) that the toxic effects 
of nitro heteroaromatics to the human host can be alleviated-and detrimental effects to the pathogen retained or even increased-by careful optimization of the molecular periphery around the nitro heteroaromatic warhead. The feasibility of such an approach has been demonstrated by the recent approval of antitubercular nitroimidazole drugs delamanid [11] and pretomanid [12] (Figure 1) which act as metabolically activated prodrugs. The progress in this field as well as the pros and cons of incorporating nitro (hetero)aromatic groups in drug candidate molecules have been comprehensively summarized in a recent review [13].
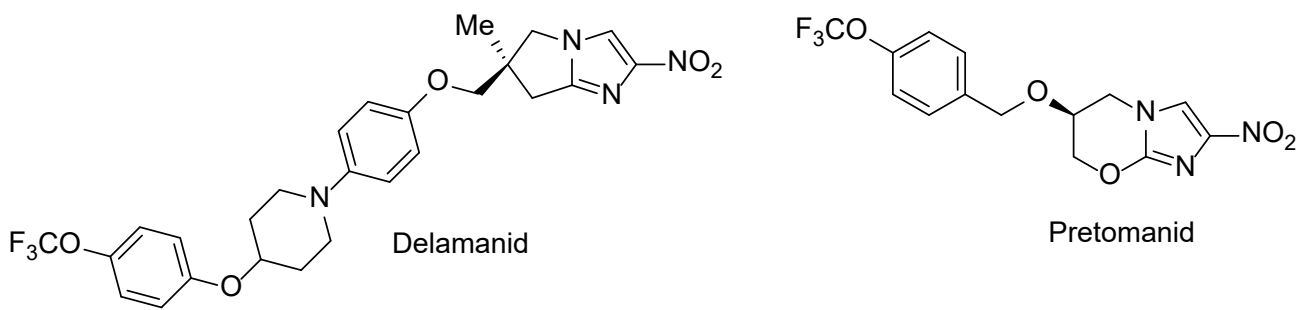

Pretomanid

Figure 1. Clinically approved drugs delamanid and pretomanid.

In our program aimed at discovering new efficacious antibacterial leads, we undertook screening of a set of diverse nitrogen heteroaromatic compounds bearing a bioreducible nitro group. From this effort, compound OTB-021 (5-methyl-7-(3-nitro-1,2,4-triazol-1-yl)-1,2,4-triazolo[1,5-a]pyrimidine) surfaced as a moderately potent hit with specific activity against drug-sensitive H37Rv strain of Mycobacterium tuberculosis [14], while other Gram-positive (S. aureus and E. faecium) or Gram-negative (E. coli, P. aeruginosa, A. baumannii, K. pneumoniae) pathogens belonging to the so-called ESKAPE panel [15] and immortalized cancer cell lines (MCF-7, FS4-LTM, KB-3-1, L929) were not affected. We hypothesized that the 4-(3-nitro-[1,2,4]-triazol-1-yl)pyrimidine portion of OTB-021 (highlighted in red) was likely responsible for its antibacterial properties, and we sought to verify this premise by simplifying the structure of this hit molecule, making it more amenable to structural variations and investigating the structure-activity relationships (SAR). To this end, we designed two isomeric series, -2- and 4-(3-nitro-1,2,4-triazol-1-yl)pyrimidines 1 and 2, bearing diverse amino side chains in positions 4 and 2 of the pyrimidine ring, respectively. The principal idea behind such a design was to reduce the bicyclic aromatic nitrogen-rich core of OTB-021 to the more druglike pyrimidine as well as to provide sufficient room for structural diversity via the side chain variation (Figure 2). Herein, we report the synthesis and comparative evaluation of the two novel series of compounds with respect to their ability to inhibit the growth of bacterial pathogens.

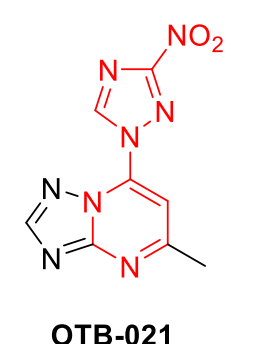

M. tuberculosis (H37Rv) MIC $12.5 \mu \mathrm{g} / \mathrm{mL}$ ESKAPE pathogens - MIC $>50 \mu \mathrm{g} / \mathrm{mL}$ MCF-7 IC I0 $>100 \mu \mathrm{M}$

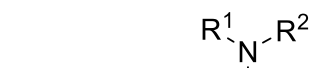<smiles>Nc1ccnc(-n2cnc([N+](=O)[O-])n2)n1</smiles>

1

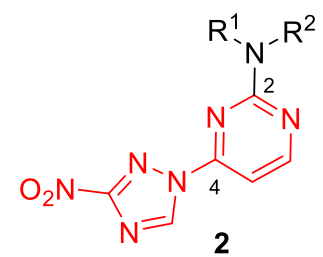

Figure 2. Structure of OTB-021 hit compound and the two isomeric series of simplified analogs (1 and 2) investigated in this work. 


\section{Results and Discussion}

\subsection{Synthesis}

\subsubsection{2-(3-Nitro-1,2,4-triazol-1-yl)pyrimidines 1}

Initially, our synthetic efforts focused on the installation of the 3-nitro-1,2,4-triazol-1-yl unit on the pyrimidine nucleus using commercially available 5-nitro- $1 \mathrm{H}-1,2,4$-triazole and 2,4-dichloropyrimidine. Firstly, it was promptly established that the reaction did not require the use of a metal-based catalyst $\left(\mathrm{Pd}^{0}\right.$ or $\left.\mathrm{Cu}^{\mathrm{I}}\right)$ and proceeded as direct nucleophilic aromatic $\left(\mathrm{S}_{N} \mathrm{Ar}\right)$ substitution. Secondly, performing the reaction in the presence of even a slight excess of the base diminished the yield as it led to the degradation of the 2,4-dichloropyrimidine starting material. Hence, 5-nitro- $1 H$-1,2,4-triazole potassium salt (3) was obtained [16] in a separate step and used in the chloride displacement reactions. Finally, we discovered that achieving a good yield of the monosubstitution product was not straightforward as even at low conversions of the monosubstitution, the product formed reacted with the second equivalent of 3 , even in the presence of unreacted 2,4-dichloropyrimidine. Considering that the 3-nitro-1,2,4-triazol-1-yl moiety itself can served as a good leaving group in $S_{N}$ Ar reactions [17], we obtained disubstituted product 4 in excellent yield (Scheme 1) and subsequently employed it in $\mathrm{S}_{N}$ Ar reactions with amines.

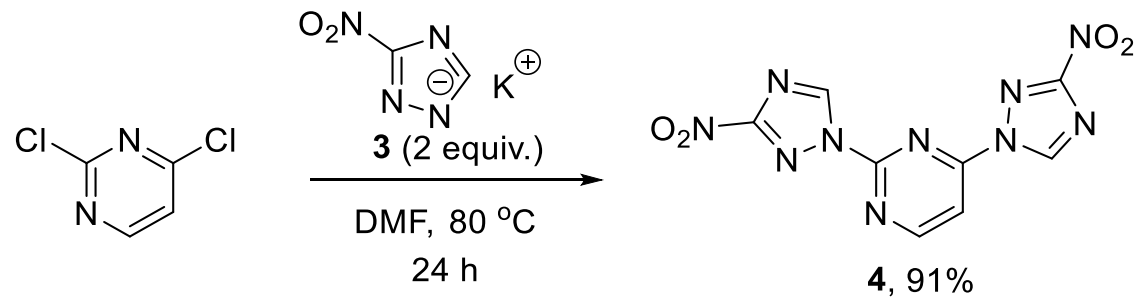

Scheme 1. Preparation of 2,4-bis(3-nitro-1H-1,2,4-triazol-1-yl)pyrimidine (4).

The $S_{N}$ Ar reactions of 4 with aliphatic amines indeed proceeded rather smoothly at room temperature in acetonitrile, while more forcing conditions (DMSO, $100{ }^{\circ} \mathrm{C}, 24-48 \mathrm{~h}$ ) had to be applied with aromatic amines. The reactions displayed a pronounced selectivity toward the displacement of the 3-nitro-1H-1,2,4-triazol-1-yl leaving group in position 4 of the pyrimidine nucleus and allowed obtaining satisfactory yields of compounds 1a-s (Table 1). Chromatographic isolation of sufficiently pure ( $>90 \%$ of purity according to ${ }^{1} \mathrm{H}$ NMR) regioisomeric products 2 from these reactions was not feasible; hence, 4-(3-nitro-1,2,4-triazol-1-yl)pyrimidines were accessed via a different strategy.

Table 1. Synthesis of 2-(3-nitro-1,2,4-triazol-1-yl)pyrimidines 1a-s.

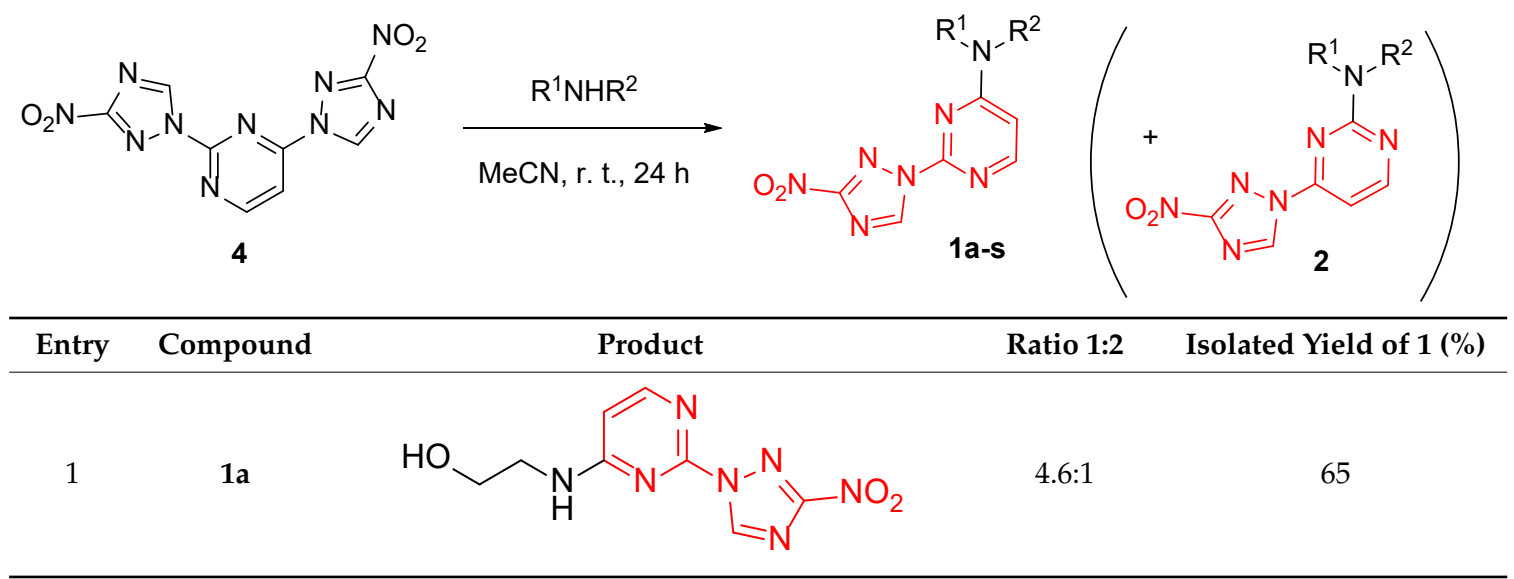


Table 1. Cont.

\begin{tabular}{|c|c|c|c|c|}
\hline Entry & Compound & Product & Ratio 1:2 & Isolated Yield of 1 (\%) \\
\hline 2 & $1 b$ & & $2.5: 1$ & 48 \\
\hline 3 & 1c & & $3.2: 1$ & 61 \\
\hline 4 & $1 d$ & & $4: 1$ & 68 \\
\hline 5 & 1e & & $11.2: 1^{a}$ & 45 \\
\hline 6 & 1f & & $4.6: 1$ & 35 \\
\hline 7 & $1 \mathrm{~g}$ & & $2.2: 1$ & 46 \\
\hline 8 & 1h & & $3.5: 1$ & 38 \\
\hline 9 & $1 \mathbf{i}$ & & $22: 1$ & 66 \\
\hline 10 & $1 j$ & & $3.5: 1$ & 39 \\
\hline 11 & $1 k$ & & $1.4: 1$ & 32 \\
\hline
\end{tabular}


Table 1. Cont.

\begin{tabular}{|c|c|c|c|c|}
\hline Entry & Compound & Product & Ratio 1:2 & Isolated Yield of $1(\%)$ \\
\hline 12 & 11 & & $1.2: 1$ & 28 \\
\hline 13 & $1 \mathrm{~m}$ & & $1.6: 1^{a}$ & 35 \\
\hline 14 & 1n & & $3.5: 1$ & 47 \\
\hline 15 & 10 & & $2.4: 1$ & 43 \\
\hline 16 & $1 p$ & & 7.2:1 & 66 \\
\hline 17 & $1 q$ & & $4: 1$ & 44 \\
\hline 18 & $1 \mathrm{r}$ & & $-b$ & 61 \\
\hline 19 & $1 \mathrm{~s}$ & & $-b$ & 19 \\
\hline
\end{tabular}

${ }^{\text {a }}$ Reactions were performed at $100{ }^{\circ} \mathrm{C}$ in DMSO over $24-48$ h. ${ }^{\mathrm{b}}$ No regioisomer was formed.

The regiochemistry of series $\mathbf{1}$ was unequivocally confirmed by the single-crystal X-ray structure obtained for compound 1e (Figure 3, Table S1).

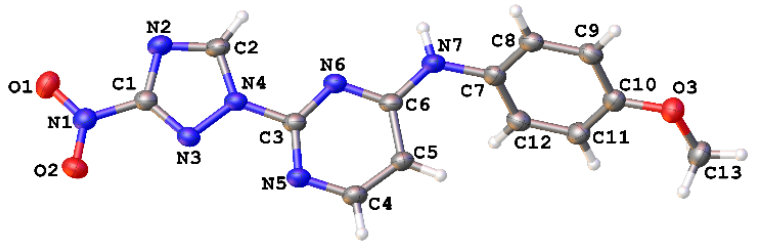

Figure 3. Single-crystal X-ray structure for compound 1e (CCDC 1582454); thermal ellipsoids are shown at $50 \%$ probability. 


\subsubsection{4-(3-Nitro-1,2,4-triazol-1-yl)pyrimidines 2}

We reasoned that the seemingly unavoidable formation of disubstituted product 4 in reactions of 3 with 2,4-dichloropyrimidine could be circumvented if excess of the latter was used while the concentration of 3 was maintained low over the course of the reaction. After substantial experimentation, we established that with 0.5 equiv. of 3 added as a DMF solution to a solution of 2,4-dichloropyrimidine in DMF using a syringe pump over $8 \mathrm{~h}$ (at a rate of about $0.82 \mathrm{mmol}$ in $2.5 \mathrm{~mL}$ per hour) at $80{ }^{\circ} \mathrm{C}$, monosubstituted 2-chloro-4-(3-nitro-1H-1,2,4-triazol-1-yl)pyrimidine (5) could be obtained in $43 \%$ yield (from 3), while unreacted 2,4-dichloropyrimidine could be isolated and utilized again. The substitution pattern of $\mathbf{5}$ was confirmed by the single-crystal X-ray analysis (Scheme 2, Table S1).
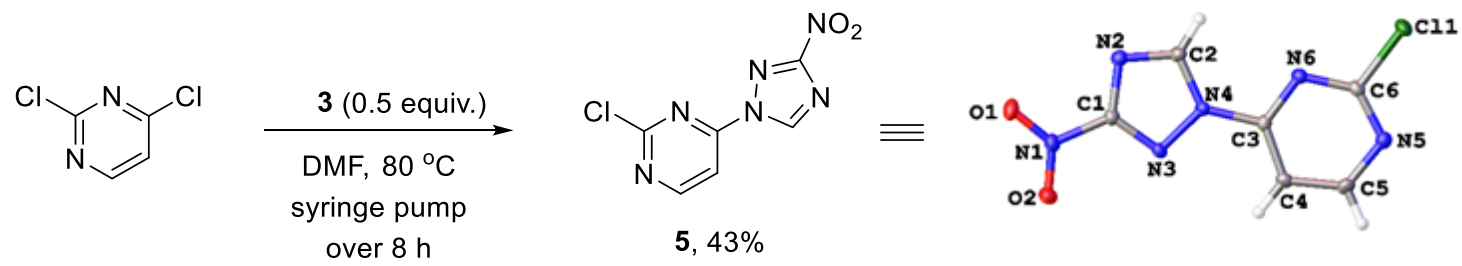

Scheme 2. Synthesis of 2-chloro-4-(3-nitro-1H-1,2,4-triazol-1-yl)pyrimidine (5) and its single-crystal X-ray structure (CCDC 1582455, thermal ellipsoids are shown at 50\% probability).

With sufficient amounts of 5 in hand, we proceeded in preparing compounds belonging to series 2 with the same set of amines as was used to prepare series 1 (to allow for direct comparison of the biological effects exerted by the two series). The substitution of the chlorine atom in position 2 with aliphatic amines generally gave moderate to high yields in acetonitrile at room temperature, while anilines, again, required heating at $100{ }^{\circ} \mathrm{C}$ in DMSO for the reaction to proceed (Table 2). Notably, in this case, no substitution of the 3-nitro-1,2,4-triazol-1-yl group in position 4 of the pyrimidine nucleus was observed.

Table 2. Synthesis of 4-(3-nitro-1,2,4-triazol-1-yl)pyrimidines 2a-s.

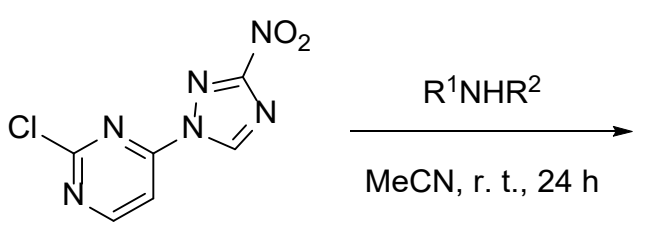

5

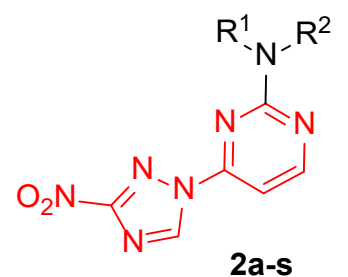

2a-s

\begin{tabular}{cccc}
\hline Entry & Compound & Yield (\%) \\
\hline & & & \\
2 & &
\end{tabular}


Table 2. Cont.

\begin{tabular}{|c|c|c|c|}
\hline Entry & Compound & Product & Yield (\%) \\
\hline 4 & $2 d$ & & 23 \\
\hline 5 & $2 e$ & & $41^{\mathrm{a}}$ \\
\hline 6 & $2 f$ & & 58 \\
\hline 7 & $2 g$ & & 75 \\
\hline 8 & $2 \mathrm{~h}$ & & 83 \\
\hline 9 & $2 i$ & & 76 \\
\hline 10 & $2 j$ & & 81 \\
\hline 11 & $2 k$ & & 44 \\
\hline 12 & 21 & & 71 \\
\hline 13 & $2 \mathrm{~m}$ & & $62^{\mathrm{a}}$ \\
\hline
\end{tabular}


Table 2. Cont.

Entry Compound

${ }^{\mathrm{a}}$ Reactions were performed at $100^{\circ} \mathrm{C}$ in DMSO over $24-48 \mathrm{~h}$.

The regiochemistry of series 2 was unequivocally confirmed by the single-crystal $\mathrm{X}$-ray structures obtained for compounds $\mathbf{2 h}, \mathbf{2 k}, \mathbf{2 n}$ and $\mathbf{2 o}$ (Figure 4, Tables S2 and S3).

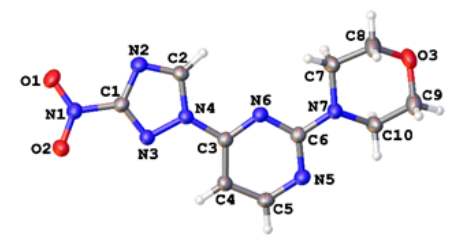

(a)

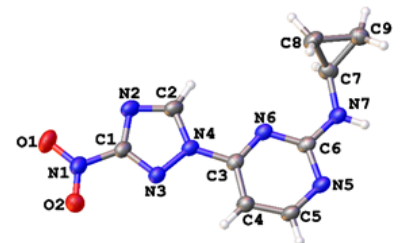

(c)

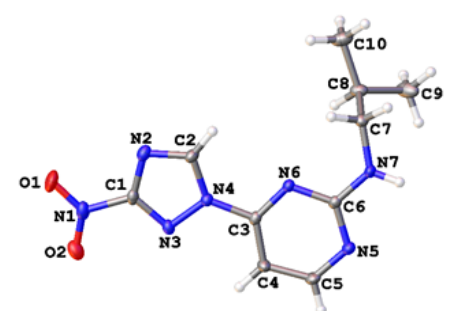

(b)

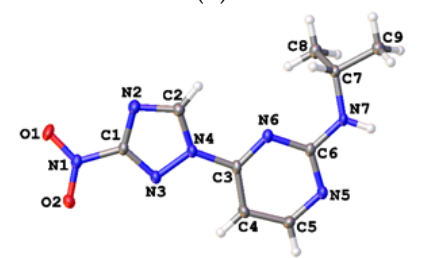

(d)

Figure 4. Single-crystal X-ray structures for compound 2h (a, CCDC 1582450), 2k (b, CCDC 1582440), 2n (c, CCDC 1582442) and 2o (d, CCDC 1582439); thermal ellipsoids are shown at 50\% probability. 


\subsection{In Vitro Biological Evaluation}

Surprisingly, when tested against the drug-sensitive H37Rv strain of Mycobacterium tuberculosis, none of the 38 compounds, 1a-s and 2a-s, displayed any appreciable activity. Gratifyingly, when screened against the ESKAPE panel of six bacterial pathogens commonly found to carry antimicrobial resistance genes [15], both series displayed a promising antibacterial profile, which is summarized in Table 3 ((bis(3-nitro-1,2,4-triazol-1-yl) compound 4 is shown for comparison and ciprofloxacin was employed as a positive control for all six microorganisms).

Table 3. Antibacterial activity (minimal inhibitory concentration, MIC) of compounds 1a-s, 2a-s, 4 and ciprofloxacin (positive control) against the ESKAPE panel of pathogens (E1 = Enterococcus faecium (G+), S = Staphylococcus aureus (G+), K = Klebsiella pneumonia (G-), A = Acinetobacter baumannii (G-), $\mathrm{P}=$ Pseudomonas aeruginosa $(\mathrm{G}-), \mathrm{E} 2=$ Enterobacter aerogenes $(\mathrm{G}-))$.<smiles>[R]N([R])c1ccnc(-n2cnc(N[O+])n2)n1</smiles>

\begin{tabular}{|c|c|c|c|c|c|c|c|c|}
\hline \multirow{2}{*}{ Entry } & \multirow{2}{*}{ Compound } & \multirow{2}{*}{$\mathbf{R}^{1} \mathrm{NR}^{2}$ Side Chain } & \multicolumn{6}{|c|}{$\mathrm{MIC}, \mu \mathrm{g} / \mathrm{mL}$} \\
\hline & & & E1 & $S$ & $\mathbf{K}$ & A & $\mathbf{P}$ & E2 \\
\hline 1 & $1 \mathrm{a}$ & \multirow{2}{*}{$\mathrm{HO} \sim \mathrm{H}_{\mathrm{H}}{ }^{-*}$} & 16 & $>100$ & $>100$ & 16 & $>100$ & $>100$ \\
\hline 2 & $2 a$ & & 8 & 63 & 8 & $>100$ & $>100$ & 63 \\
\hline 3 & $1 b$ & & 8 & $>100$ & $>100$ & 4 & $>100$ & $>100$ \\
\hline 4 & $2 b$ & & 8 & $>100$ & 2 & 2 & $>100$ & 8 \\
\hline 5 & 1c & \multirow[b]{2}{*}{$\mathrm{H}$} & 16 & $>100$ & $>100$ & 4 & $>100$ & $>100$ \\
\hline 6 & $2 c$ & & 63 & $>100$ & $>100$ & 8 & $>100$ & $>100$ \\
\hline 7 & 1d & \multirow[b]{2}{*}{$1>1$} & 8 & 16 & 32 & $>100$ & $>100$ & 63 \\
\hline 8 & $2 d$ & & 8 & 63 & 16 & $>100$ & $>100$ & 63 \\
\hline 9 & 1e & \multirow{4}{*}{ (N) } & 4 & $>100$ & 63 & $>100$ & $>100$ & $>100$ \\
\hline 10 & $2 \mathrm{e}$ & & 8 & 8 & $>100$ & 4 & $>100$ & 63 \\
\hline 11 & 1f & & 4 & $>100$ & $>100$ & 8 & $>100$ & $>100$ \\
\hline 12 & $2 f$ & & 8 & 63 & 8 & 32 & $>100$ & 16 \\
\hline 13 & $1 \mathrm{~g}$ & \multirow{2}{*}{$\mathrm{H}$} & 4 & $>100$ & $>100$ & 32 & $>100$ & $>100$ \\
\hline 14 & $2 \mathrm{~g}$ & & 32 & $>100$ & $>100$ & 8 & $>100$ & 63 \\
\hline 15 & 1h & \multirow[b]{2}{*}{$\mathrm{N}-{ }^{*}$} & 16 & $>100$ & $>100$ & 32 & $>100$ & $>100$ \\
\hline 16 & $2 \mathrm{~h}$ & & 4 & 16 & $>100$ & 63 & $>100$ & $>100$ \\
\hline 17 & $1 \mathrm{i}$ & \multirow{2}{*}{$-\mathrm{N} \quad \mathrm{N}^{*}$} & 2 & 4 & 32 & 32 & $>100$ & 32 \\
\hline 18 & $2 i$ & & 2 & $>100$ & $>100$ & $>100$ & $>100$ & $>100$ \\
\hline 19 & $\mathbf{1 j}$ & & 4 & $>100$ & $>100$ & 4 & $>100$ & $>100$ \\
\hline 20 & $2 j$ & & 8 & $>100$ & $>100$ & 63 & $>100$ & $>100$ \\
\hline 21 & $1 \mathrm{k}$ & \multirow{2}{*}{$\widehat{\mathrm{H}^{\prime}}$} & 2 & 63 & $>100$ & $>100$ & $>100$ & $>100$ \\
\hline 22 & $2 k$ & & $>100$ & $>100$ & $>100$ & 4 & $>100$ & $>100$ \\
\hline 23 & 11 & \multirow{2}{*}{$\mathrm{NO}^{-*}$} & 63 & $>100$ & $>100$ & 4 & $>100$ & $>100$ \\
\hline 24 & 21 & & 16 & 16 & $>100$ & 8 & $>100$ & $>100$ \\
\hline
\end{tabular}


Table 3. Cont.

\begin{tabular}{|c|c|c|c|c|c|c|c|c|}
\hline \multirow{2}{*}{ Entry } & \multirow{2}{*}{ Compound } & \multirow{2}{*}{$\mathbf{R}^{1} \mathbf{N R}^{2}$ Side Chain } & \multicolumn{6}{|c|}{$\mathrm{MIC}, \mu \mathrm{g} / \mathrm{mL}$} \\
\hline & & & E1 & $S$ & $\mathbf{K}$ & A & $\mathbf{P}$ & E2 \\
\hline 25 & $1 \mathrm{~m}$ & & 8 & 8 & 32 & 2 & $>100$ & 16 \\
\hline 26 & $2 m$ & & 16 & $>100$ & $>100$ & 8 & $>100$ & $>100$ \\
\hline 27 & $1 n$ & & $>100$ & $>100$ & $>100$ & $>100$ & $>100$ & $>100$ \\
\hline 28 & $2 n$ & & 4 & 32 & $>100$ & 63 & $>100$ & $>100$ \\
\hline 29 & 10 & & 2 & 4 & 16 & 32 & $>100$ & 32 \\
\hline 30 & 20 & & $>100$ & $>100$ & $>100$ & 8 & $>100$ & $>100$ \\
\hline 31 & $1 p$ & & 32 & $>100$ & $>100$ & 8 & $>100$ & $>100$ \\
\hline 32 & $2 p$ & & 4 & $>100$ & $>100$ & 8 & $>100$ & $>100$ \\
\hline 33 & $1 \mathrm{q}$ & & 16 & $>100$ & $>100$ & 4 & $>100$ & $>100$ \\
\hline 34 & $2 q$ & & 32 & 63 & $>100$ & 16 & $>100$ & $>100$ \\
\hline 35 & $1 \mathrm{r}$ & & 16 & $>100$ & $>100$ & 8 & $>100$ & 63 \\
\hline 36 & $2 r$ & & 16 & 63 & $>100$ & $>100$ & $>100$ & $>100$ \\
\hline 37 & 1s & & 16 & 63 & 63 & $>100$ & $>100$ & $>100$ \\
\hline 38 & $2 s$ & $\mathrm{MeC}$ & 2 & $>100$ & $>100$ & 4 & $>100$ & $>100$ \\
\hline 39 & 4 & & 32 & $>100$ & $>100$ & $>100$ & $>100$ & $>100$ \\
\hline 40 & & floxacin & 0.3 & 1.25 & 0.6 & 2.5 & 0.6 & 1.25 \\
\hline
\end{tabular}

* Attachment to position 4 in triazolopyrimidine scaffold (compounds 1) or position 2 (compounds 2).

Several important observations emerge from the data presented in Table 3. Firstly, (bis(3-nitro-1,2, 4-triazol-1-yl) compound 4 was virtually inactive (except for marginal activity on E. faecium). This clearly demonstrates that the combination of only one 3-nitro-1,2,4-triazol-1-yl moiety with an electron-donating amino substituent is the correct definition of the pharmacophore of both series 1 and 2. Secondly, there appears no apparent biologic activity dependence on the relative position of the two groups around the pyrimidine nucleus. Quite frequently, the high antibacterial potency of series $\mathbf{2}$ compounds was lost on switching to series $\mathbf{1}$ (cf. $\mathbf{2} \mathbf{a} \rightarrow \mathbf{1} \mathbf{a}, \mathbf{2} \mathbf{b} \rightarrow \mathbf{1} \mathbf{b}, \mathbf{2} \mathbf{f} \rightarrow \mathbf{1 f}$ vs. K. pneumonia; $\mathbf{2 e} \rightarrow \mathbf{1 e}$, $\mathbf{2 k} \rightarrow \mathbf{1 k}, \mathbf{2 s} \rightarrow \mathbf{1 s}$ vs. A. baumannii; $\mathbf{2 e} \rightarrow \mathbf{1 e}$ vs. S. aureus; $\mathbf{2} \mathbf{n} \rightarrow \mathbf{1} \mathbf{n}$ vs. E. faecium; $\mathbf{2} \mathbf{b} \rightarrow \mathbf{1 b}$ vs. E. aerogenes). Less frequently, the opposite was true and series $\mathbf{1}$ was highly active, while series $\mathbf{2}$ was not (cf. $\mathbf{1} \mathbf{i} \rightarrow \mathbf{2 i}$ and $\mathbf{1 m} \rightarrow \mathbf{2 m}$ vs. S. aureus; $\mathbf{1} \mathbf{j} \rightarrow \mathbf{2} \mathbf{j}$ and $\mathbf{1} \mathbf{r} \rightarrow \mathbf{2 r}$ vs. A. baumannii; $\mathbf{1 0} \rightarrow \mathbf{2 o}$ vs. S. aureus and E. faecium). It is an accepted view that the antibacterial activity of bioreducible nitro heteroaromatic compounds with respect to a particular bacterial species, among other factors, will depend on their ability to be metabolically activated by the membrane-bound nitro reductase enzyme of that species [18] as well as on the ability of the resulting reactive chemical entity to cross the bacterial membrane and damage the pathogen's DNA [19]. Considering such a multifactorial nature of the observed inhibitory effects on bacterial growth, it is unsurprising that no definitive bioactivity pattern between series $\mathbf{1}$ and 2 emerged.

Other notable features of the bioactivity profile of the compounds 1a-s and 2a-s include the complete absence of activity against $P$. aeruginosa and the distinct susceptibility of $A$. baumannii to many compounds in the investigated set. In fact, some of the compounds (cf. $\mathbf{1 b}, \mathbf{1 c}, \mathbf{1 j}, \mathbf{1}, \mathbf{1 m}, \mathbf{1 q}, \mathbf{2 b}, \mathbf{2 e}, \mathbf{2 k}$, 2s) displayed MIC values comparable or even lower than those displayed by ciprofloxacin towards this particular pathogen. Another pathogen that demonstrated susceptibility to a number of compounds tested is E. faecium. However, the best MIC values achieved in this case $(2 \mu \mathrm{g} / \mathrm{mL})$ are six times lower than the respective value for ciprofloxacin. At the same time, the activity of compounds $\mathbf{1 i}$ and $\mathbf{1 o}$ is only three times lower with respect to $S$. aureus than that of the comparator drug. Compound $\mathbf{2 b}$ certainly leads the way in terms of the single-digit $\mu \mathrm{g} / \mathrm{mL}$ activity displayed across the panel, strongly 
inhibiting the growth of E. faecium, K. pneumonia, A. baumannii and E. aerogenes. In contrast, compounds 2c, 2k, 11 and 20 appear to be distinctly selective towards $A$. baumannii, which is a characteristic tendency of the entire set. The complete absence of activity across the ESKAPE panel displayed by compound $1 \mathrm{n}$ is somewhat surprising and, again, attests to the multifactorial nature of the bioactivity patterns observed.

\subsection{Electrochemical Behavior}

Since it was hypothesized that, like other nitro (hetero)aromatic drugs [20], (3-nitro-1,2,4-triazol1-yl)pyrimidines $\mathbf{1}$ and $\mathbf{2}$ investigated in this work are activated via the nitro group reduction by the bacterial nitroreductase, we investigated the electrochemical behavior of selected compounds from both series using cyclic voltammetry. The aim of this effort was to establish if there is an apparent correlation of the antibacterial properties against any bacterial species (as was reported for some antimicrobial nitroaromatic compounds [21] as well as metal chelate complexes [22]) and the compounds' reduction potential. Additionally, we thought it interesting to obtain a pairwise comparison of the reduction potential of series 1 and $\mathbf{2}$ compounds which might shed light on some of the bioactivity trends noted above.

Considering the apparent difference in the activity trends against different pathogens of the ESKAPE panel, we focused on the activity against one specific pathogen, E. faecium, in nominating compounds for cyclic voltammetry experiments. To this end, we selected highly potent (1i, $\mathbf{1 j}, \mathbf{2} \mathbf{i})$, moderately potent $(\mathbf{1 m}, \mathbf{2} \mathbf{b}, \mathbf{2 e}, \mathbf{2 r})$ and inactive (1n) compounds with respect to this pathogen. Cyclic voltammograms obtained for these compounds relative to the ferrocene external standard demonstrate a one-electron reduction $\left(\mathrm{Het} A \mathrm{NO}_{2} \rightarrow \mathrm{Het} \mathrm{ArNO}_{2}{ }^{-}\right.$) and a reversible oxidation $\left(\right.$ HetArNO$\left.{ }_{2}{ }^{-} \rightarrow \mathrm{HetArNO}_{2}\right)$ wave with reduction potentials $\left(\mathrm{E}_{1 / 2}\right)$ tightly grouped in the $-1.3--1.1 \mathrm{~V}$ range (Figure 5).

As it follows from the data collated in Table 4, there appears no apparent correlation between the activity displayed by the nine compounds investigated against E. faecium and their reduction potential. A brief glance at the activity data against the other five pathogens revealed that there is no correlation with the reduction potential either. This strongly suggests that, as noted previously, there are likely other factors at play, besides the compounds' reduction potential, which determine the observed antibacterial activity. This being said, however, one can note the generally more negative $\mathrm{E}_{1 / 2}$ values observed for the series 1 compounds. All other factors being equal, this (i.e., the lower tendency of compounds 1 to undergo a one-electron reduction compared to compounds 2) could be the likely reason for the frequently observed activity loss on switching from series 2 to series $\mathbf{1}$.

Table 4. Reduction potentials $\left(\mathrm{E}_{1 / 2}, \mathrm{~V}\right)$ of selected compounds $\mathbf{1}$ and $\mathbf{2}$ and their MIC values $(\mu \mathrm{g} / \mathrm{mL})$ observed against E. faecium.

\begin{tabular}{ccccc}
\hline Entry & Compound & $\begin{array}{c}\mathrm{E}_{\mathbf{1} / \mathbf{2}} \\
\left(\mathbf{V ~ v s . ~} \mathbf{A g} / \mathbf{A g}^{+}\right)\end{array}$ & $\begin{array}{c}\mathrm{E}_{\mathbf{1} / \mathbf{2}} \\
(\mathbf{V} \text { vs. Fc/Fc }\end{array}$ & $\begin{array}{c}\text { E. faecium MIC } \\
(\mu \mathbf{g} / \mathbf{m L})\end{array}$ \\
\hline 1 & $\mathbf{1 i}$ & -1.253 & -1.439 & 2 \\
\hline 2 & $\mathbf{1 j}$ & -1.262 & -1.447 & 4 \\
\hline 3 & $\mathbf{1 m}$ & -1.246 & -1.432 & 8 \\
\hline 4 & $\mathbf{1 n}$ & -1.255 & -1.441 & $>100$ \\
\hline 5 & $\mathbf{2 b}$ & -1.195 & 1.381 & 8 \\
\hline 6 & $\mathbf{2 e}$ & -1.178 & -1.364 & 8 \\
\hline 7 & $\mathbf{2 i}$ & -1.192 & -1.378 & 2 \\
\hline 8 & $\mathbf{2 r}$ & -1.196 & -1.382 & 16 \\
\hline 9 & ferrocene & 0.186 & 0.000 & - \\
\hline
\end{tabular}




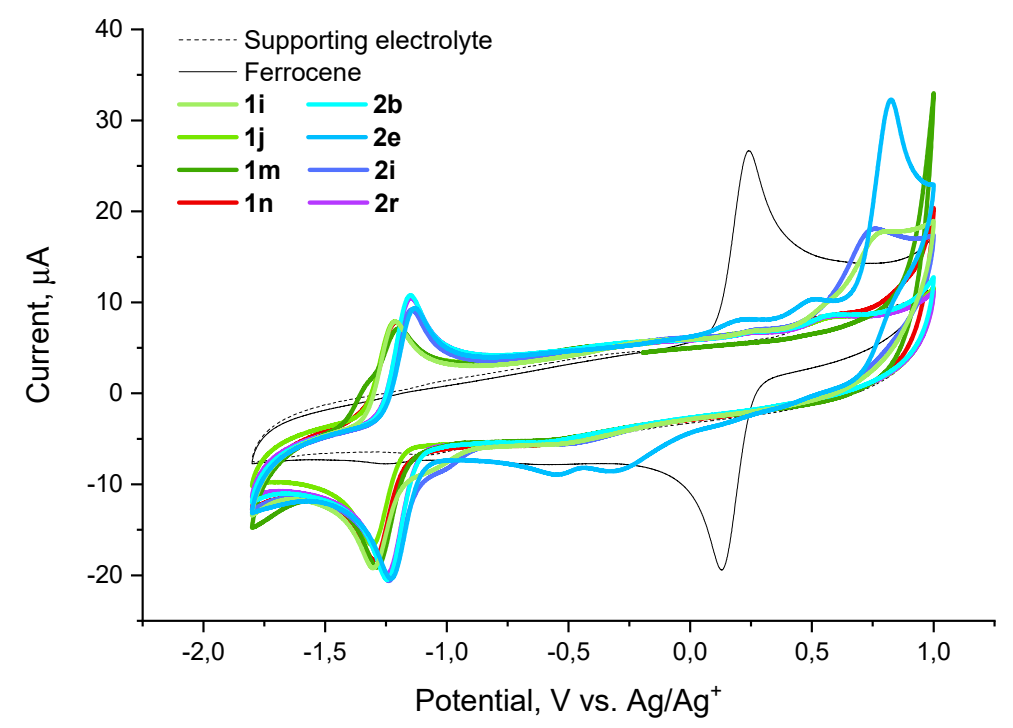

(A)

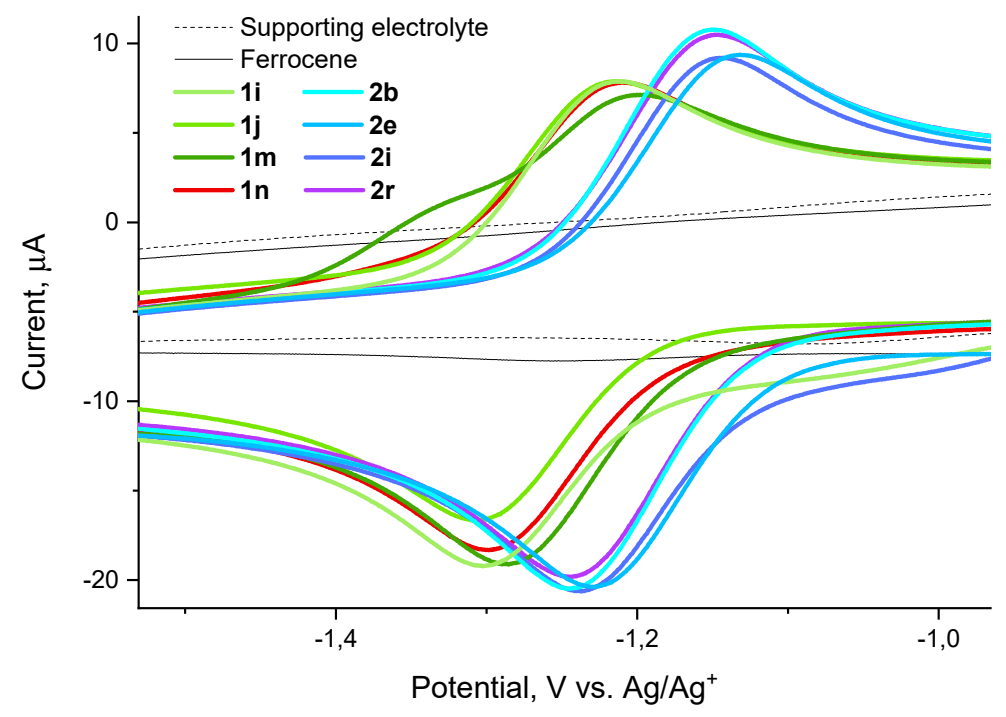

(B)

Figure 5. Cyclic voltammograms for compounds $\mathbf{1 i}, \mathbf{1} \mathbf{j}, \mathbf{1 m}, \mathbf{1} \mathbf{n}, \mathbf{2} \mathbf{b}, \mathbf{2 e}, \mathbf{2} \mathbf{i}$ and $\mathbf{2} \mathbf{r}$ obtained relative to the ferrocene standard: (A) full view, (B) redox wave close-up.

\section{Conclusions}

Starting from the structure of antimycobacterial screening hit OTB-021 which was devoid of activity against ESKAPE pathogens, we designed, synthesized and tested two mutually isomeric series of novel simplified analogs, 2- and 4-(3-nitro-1,2,4-triazol-1-yl)pyrimidines (series 1 and 2), bearing various amino side chains. These compounds demonstrated a reverse bioactivity profile being inactive against $M$. tuberculosis while inhibiting the growth of all ESKAPE pathogens (with variable potency patterns) except for Gram-negative P. aeruginosa. The observed inhibitory patterns allowed drawing some generalizations. In particular, frequent loss of activity on switching from series 2 to series 1 with the same substituents was noted (although, less frequently, the opposite trend was observed). Measurement of the reduction potentials $\left(\mathrm{E}_{1 / 2}\right)$ by cyclic voltammetry for compounds selected based on their activity against $E$. faecium revealed that all compounds investigated displayed a reversible single-electron reduction with the $E_{1 / 2}$ values tightly grouped in the $-1.3--1.1 \mathrm{~V}$ range. 
No apparent correlation between the $\mathrm{E}_{1 / 2}$ values and the ESKAPE minimum inhibitory concentrations was established, suggesting possible significance of other factors, besides the compounds' reduction potential, which determine the observed antibacterial activity. However, the frequent SAR trend noted above (the absence of activity for series $\mathbf{1}$ analogs while series $\mathbf{2}$ counterparts are active) correlates with the generally more negative $E_{1 / 2}$ values displayed by series 1 . Collectively, these findings fortify the position of bioreducible nitro heteroaromatic chemotypes as antibacterial leads.

\section{Materials and Methods}

\subsection{General Experimental}

All commercial reagents and solvents were used without further purification, unless otherwise noted. Analytical thin-layer chromatography was carried out on UV-254 silica gel plates using appropriate eluents. Compounds were visualized with short-wavelength UV light. NMR spectroscopic data were recorded with a Bruker Avance 400 spectrometer $\left(400.13 \mathrm{MHz}\right.$ for ${ }^{1} \mathrm{H}$ and $100.61 \mathrm{MHz}$ for $\left.{ }^{13} \mathrm{C}\right)$ DMSO- $d_{6}$ and were referenced to the residual solvent proton signal $(2.51 \mathrm{ppm}$,$) and solvent$ carbon signal (39.5 ppm). Melting points were determined with a Stuart SMP50 instrument in open capillary tubes. Mass spectra were recorded with a Bruker Maxis HRMS-ESI-qTOF spectrometer (electrospray ionization mode). Electrochemical measurements were performed with the Autolab PGSTAT30 (EcoChemie, The Netherlands) potentiostat/galvanostat.

\subsection{Synthetic Organic Chemistry}

\subsubsection{Preparation of 2,4-bis(3-nitro-1H-1,2,4-triazol-1-yl)pyrimidine (4)}

A round-bottom flask equipped with a magnetic stir bar was charged with 2,4-dichloropyrimidine ( $3 \mathrm{~g}, 20.14 \mathrm{mmol})$, potassium 3-nitro-1,2,4-triazol-1-ide $(3,6.13 \mathrm{~g}, 40.28 \mathrm{mmol})$ and dry DMF $(40 \mathrm{~mL})$. The reaction mixture was stirred at $80^{\circ} \mathrm{C}$ for $24 \mathrm{~h}$, cooled to room temperature and concentrated under reduced pressure. The residue was taken up in distilled water $(100 \mathrm{~mL})$ and the resulting suspension was filtered. The solid was washed with another distilled water $(100 \mathrm{~mL})$ and air-dried to afford the title compound $(5.61 \mathrm{~g}, 92 \%)$ as a beige solid, $\mathrm{mp} 246-248{ }^{\circ} \mathrm{C} .{ }^{1} \mathrm{H}$ NMR $\left(400 \mathrm{MHz}, \mathrm{DMSO}-d_{6}\right) \delta 10.20(\mathrm{~s}$, $1 \mathrm{H}$, triazole), $10.14(\mathrm{~s}, 1 \mathrm{H}$, triazole $), 9.30\left(\mathrm{~d}, J=5.5 \mathrm{~Hz}, 1 \mathrm{H}, \mathrm{H}_{\mathrm{Ar}}\right), 8.18\left(\mathrm{~d}, J=5.5 \mathrm{~Hz}, 1 \mathrm{H}, \mathrm{H}_{\mathrm{Ar}}\right) .{ }^{13} \mathrm{C} \mathrm{NMR}$ $\left(101 \mathrm{MHz}\right.$, DMSO- $\left.d_{6}\right) \delta 164.7,163.8,163.7,155.7,153.0,148.2,147.2,110.4$. HRMS-ESI $(\mathrm{m} / \mathrm{z})$ : calcd for $\mathrm{C}_{8} \mathrm{H}_{4} \mathrm{~N}_{10} \mathrm{KO}_{4}[\mathrm{M}+\mathrm{K}]: 343.0049$; found: 343.0055 .

\subsubsection{General Procedure 2 (GP2) for the Preparation of Compounds 1a-d, $\mathbf{1} \mathbf{f}-\mathbf{1}$ and $\mathbf{1 n}-\mathbf{s}$}

A glass screw-capped vial containing a magnetic stir bar was charged with 2,4-bis(3-nitro-1H1,2,4-triazol-1-yl)pyrimidine (4) $(0.98 \mathrm{mmol}, 300 \mathrm{mg})$, amine $(1.97 \mathrm{mmol})$ and acetonitrile $(3 \mathrm{~mL})$. The suspension was stirred at room temperature. After completion of the reaction (TLC analysis), the solvent was removed in vacuo. The resulting solid was suspended in water $(5 \mathrm{~mL})$ and the suspension was placed in a fridge. After $2 \mathrm{~h}$, the resulting thick precipitate was filtered off, dissolved in ethyl acetate, absorbed on silica gel (ca $0.3 \mathrm{~g}$ ) and loaded on a silica gel chromatographic column. Elution with ethyl acetate- $n$-hexane (1:2) afforded an analytically pure product.

2-((2-(3-Nitro-1H-1,2,4-triazol-1-yl)pyrimidin-4-yl)amino)ethan-1-ol (1a)

Prepared according to GP2 using 2-aminoethan-1-ol. Beige solid, yield 65\%; mp 212-214 ${ }^{\circ} \mathrm{C}$ (decomp.). ${ }^{1} \mathrm{H}$ NMR $\left(400 \mathrm{MHz}\right.$, DMSO- $\left.d_{6}\right) \delta 9.48\left(\mathrm{~s}, 1 \mathrm{H}\right.$, triazole), $8.15\left(\mathrm{~d}, J=6.0 \mathrm{~Hz}, 1 \mathrm{H}, \mathrm{H}_{\mathrm{Ar}}\right), 7.91(\mathrm{~s}$, $1 \mathrm{H}, \mathrm{NH}), 6.67\left(\mathrm{~d}, J=6.0 \mathrm{~Hz}, 1 \mathrm{H}, \mathrm{H}_{\mathrm{Ar}}\right), 4.54(\mathrm{~s}, 1 \mathrm{H}, \mathrm{OH}), 3.63\left(\mathrm{t}, J=5.8 \mathrm{~Hz}, 2 \mathrm{H}, \mathrm{CH}_{2}\right), 3.58-3.38(\mathrm{~m}, 2 \mathrm{H}$, $\left.\mathrm{CH}_{2}\right) ;{ }^{13} \mathrm{C}$ NMR $\left(101 \mathrm{MHz}, \mathrm{DMSO}-d_{6}\right) \delta 163.7,163.2,154.9,153.6,146.5,107.1,59.8,43.2$. HRMS-ESI $(\mathrm{m} / \mathrm{z})$ : calcd for $\mathrm{C}_{8} \mathrm{H}_{9} \mathrm{~N}_{7} \mathrm{NaO}_{3}$ [M + Na]: 274.0659; found: 274.0667 . 
N,N-Dimethyl-2-(3-nitro-1H-1,2,4-triazol-1-yl)pyrimidin-4-amine (1b)

Prepared according to GP2 using dimethylamine. Yellow solid, yield $48 \%$; mp 207-209 ${ }^{\circ} \mathrm{C} .{ }^{1} \mathrm{H}$ NMR $\left(400 \mathrm{MHz}, \mathrm{DMSO}-d_{6}\right) \delta 9.56\left(\mathrm{~s}, 1 \mathrm{H}\right.$, triazole), $8.28\left(\mathrm{~d}, J=6.2 \mathrm{~Hz}, 1 \mathrm{H}, \mathrm{H}_{\mathrm{Ar}}\right), 6.81(\mathrm{~d}, J=6.2 \mathrm{~Hz}, 1 \mathrm{H}$, $\left.\mathrm{H}_{\mathrm{Ar}}\right), 3.19\left(\mathrm{~s}, 6 \mathrm{H}, \mathrm{CH}_{3}\right) .{ }^{13} \mathrm{C}$ NMR $\left(126 \mathrm{MHz}\right.$, DMSO-d $\left.d_{6}\right) \delta 163.2,162.8,156.5,153.1,146.7,104.0,37.8$, 37.1. HRMS-ESI $(\mathrm{m} / \mathrm{z})$ : calcd for $\mathrm{C}_{8} \mathrm{H}_{9} \mathrm{~N}_{7} \mathrm{NaO}_{2}[\mathrm{M}+\mathrm{Na}$ ]: 258.0710; found: 258.0721 .

N-Methyl-2-(3-nitro-1H-1,2,4-triazol-1-yl)pyrimidin-4-amine (1c)

Prepared according to GP2 using methanamine. Beige solid, yield $61 \%$; $\mathrm{mp} 235-237^{\circ} \mathrm{C}$ (decomp.). ${ }^{1} \mathrm{H}$ NMR $\left(400 \mathrm{MHz}\right.$, DMSO- $\left.d_{6}\right) \delta 9.50(\mathrm{~s}, 1 \mathrm{H}$, triazole $), 8.16\left(\mathrm{~d}, J=5.6 \mathrm{~Hz}, 1 \mathrm{H}, \mathrm{H}_{\mathrm{Ar}}\right), 7.98-7.83(\mathrm{~s}, 1 \mathrm{H}$, $\mathrm{NH}), 6.61\left(\mathrm{~d}, J=6.0 \mathrm{~Hz}, 1 \mathrm{H}, \mathrm{H}_{\mathrm{Ar}}\right), 2.95\left(\mathrm{~d}, J=4.8 \mathrm{~Hz}, 3 \mathrm{H}, \mathrm{CH}_{3}\right) .{ }^{13} \mathrm{C} \mathrm{NMR}\left(101 \mathrm{MHz}, \mathrm{DMSO}-d_{6}\right) \delta$ $168.8,167.9,159.5,158.4,151.1,111.7,32.2$. HRMS-ESI $(\mathrm{m} / \mathrm{z})$ : calcd for $\mathrm{C}_{7} \mathrm{H}_{8} \mathrm{~N}_{7} \mathrm{O}_{2}[\mathrm{M}+\mathrm{H}]$ : 222.0734; found: 222.0729 .

N-Benzyl-N-methyl-2-(3-nitro-1H-1,2,4-triazol-1-yl)pyrimidin-4-amine (1d)

Prepared according to GP2 using N-methyl-1-phenylmethanamine. Green solid, yield 68\%; mp 131-133 ${ }^{\circ} \mathrm{C}$ (decomp.). ${ }^{1} \mathrm{H}$ NMR (400 MHz, DMSO- $\left.d_{6}\right) \delta 9.56(\mathrm{~s}, 1 \mathrm{H}$, triazole), $8.31(\mathrm{~d}, J=6.1 \mathrm{~Hz}, 1 \mathrm{H}$, $\left.\mathrm{H}_{\mathrm{Ar}}\right), 7.44-7.22\left(\mathrm{~m}, 5 \mathrm{H}, \mathrm{H}_{\mathrm{Ar}}\right), 6.87\left(\mathrm{~d}, J=6.2 \mathrm{~Hz}, 1 \mathrm{H}, \mathrm{H}_{\mathrm{Ar}}\right), 4.92\left(\mathrm{~s}, 2 \mathrm{H}, \mathrm{CH}_{2}\right), 3.19\left(\mathrm{~s}, 3 \mathrm{H}, \mathrm{CH}_{3}\right) .{ }^{13} \mathrm{C} \mathrm{NMR}$ (101 MHz, DMSO) $\delta$ 163.1, 157.0, 153.3, 146.5, 137.3, 129.0, 127.8, 127.8, 104.2, 52.8, 36.1. HRMS-ESI $(\mathrm{m} / \mathrm{z})$ : calcd for $\mathrm{C}_{\mathbf{1 4}} \mathrm{H}_{\mathbf{1 3}} \mathrm{N}_{7} \mathrm{NaO}_{\mathbf{2}}[\mathrm{M}+\mathrm{Na}$ ]: 334.1023; found: 334.1034.

3-((2-(3-Nitro-1H-1,2,4-triazol-1-yl)pyrimidin-4-yl)amino)propan-1-ol (1f)

Prepared according to GP2 using 3-aminopropan-1-ol. White solid, yield 35\%; mp 201-203 ${ }^{\circ} \mathrm{C}$ (decomp.). ${ }^{1} \mathrm{H}$ NMR (400 MHz, DMSO- $\left.d_{6}\right) \delta 9.48\left(\mathrm{~s}, 1 \mathrm{H}\right.$,triazole), $8.15\left(\mathrm{~d}, J=5.9 \mathrm{~Hz}, 1 \mathrm{H}, \mathrm{H}_{\mathrm{Ar}}\right), 7.91$ (s, $1 \mathrm{H}, \mathrm{NH}), 6.62\left(\mathrm{~d}, J=6.0 \mathrm{~Hz}, 1 \mathrm{H}, \mathrm{H}_{\mathrm{Ar}}\right), 4.29(\mathrm{t}, J=5.2 \mathrm{~Hz}, 1 \mathrm{H}, \mathrm{OH}), 3.54\left(\mathrm{~m}, 2 \mathrm{H}, \mathrm{CH}_{2}\right), 3.50-3.38(\mathrm{~m}, 2 \mathrm{H}$, $\left.\mathrm{CH}_{2}\right), 1.78\left(\mathrm{q}, J=6.6 \mathrm{~Hz}, 2 \mathrm{H}, \mathrm{CH}_{2}\right) .{ }^{13} \mathrm{C} \mathrm{NMR}\left(101 \mathrm{MHz}, \mathrm{DMSO}-d_{6}\right) \delta 163.6,163.2,154.9,153.6,146.5$, 106.9, 58.8, 37.7, 32.3. HRMS-ESI $(m / z)$ : calcd for $\mathrm{C}_{9} \mathrm{H}_{11} \mathrm{~N}_{7} \mathrm{NaO}_{3}[\mathrm{M}+\mathrm{Na}]$ : 288.0816; found: 288.0823 .

N-Ethyl-2-(3-nitro-1H-1,2,4-triazol-1-yl)pyrimidin-4-amine (19)

Prepared according to GP2 using ethanamine. White solid, yield $46 \%$; $\mathrm{mp} 171-173{ }^{\circ} \mathrm{C}$ (decomp.). ${ }^{1} \mathrm{H}$ NMR $\left(400 \mathrm{MHz}\right.$, DMSO- $\left.d_{6}\right) \delta 9.48(\mathrm{~s}, 1 \mathrm{H}$, triazole $), 8.16\left(\mathrm{~d}, J=6.1 \mathrm{~Hz}, 1 \mathrm{H}, \mathrm{H}_{\mathrm{Ar}}\right), 7.94(\mathrm{~s}, 1 \mathrm{H}, \mathrm{NH})$, $6.60\left(\mathrm{~d}, J=6.0 \mathrm{~Hz}, 1 \mathrm{H}, \mathrm{H}_{\mathrm{Ar}}\right), 3.44\left(\mathrm{t}, J=6.9 \mathrm{~Hz}, 2 \mathrm{H}, \mathrm{CH}_{2}\right), 1.21\left(\mathrm{t}, J=7.2 \mathrm{~Hz}, 3 \mathrm{H}, \mathrm{CH}_{3}\right) .{ }^{13} \mathrm{C} \mathrm{NMR}$ $\left(101 \mathrm{MHz}, \mathrm{DMSO}-d_{6}\right) \delta 163.4,163.2,154.9,153.7,146.5,106.9,35.4,14.6$. HRMS-ESI $(\mathrm{m} / \mathrm{z})$ : calcd for $\mathrm{C}_{8} \mathrm{H}_{9} \mathrm{~N}_{7} \mathrm{NaO}_{2}$ [M + Na]: 258.0710; found: 258.0704.

4-(2-(3-Nitro-1H-1,2,4-triazol-1-yl)pyrimidin-4-yl)morpholine (1h)

Prepared according to GP2 using morpholine. White solid, yield 38\%; mp 212-214 ${ }^{\circ} \mathrm{C}$ (decomp.). ${ }^{1} \mathrm{H}$ NMR $\left(400 \mathrm{MHz}\right.$, DMSO- $\left.d_{6}\right) \delta 9.76\left(\mathrm{~s}, 1 \mathrm{H}\right.$, triazole), $8.66\left(\mathrm{~d}, J=5.2 \mathrm{~Hz}, 1 \mathrm{H}, \mathrm{H}_{\mathrm{Ar}}\right), 7.10(\mathrm{~d}, J=5.2 \mathrm{~Hz}$, $\left.1 \mathrm{H}, \mathrm{H}_{\mathrm{Ar}}\right), 3.86\left(\mathrm{dd}, J=5.6,4.1 \mathrm{~Hz}, 4 \mathrm{H}, \mathrm{CH}_{2}\right), 3.72\left(\mathrm{dd}, J=5.7,4.1 \mathrm{~Hz}, 4 \mathrm{H}, \mathrm{CH}_{2}\right) .{ }^{13} \mathrm{C} \mathrm{NMR}(101 \mathrm{MHz}$, DMSO- $\left.d_{6}\right) \delta 163.2,162.5,157.3,153.3,146.8,104.2,66.2,44.5$. HRMS-ESI $(m / z)$ : calcd for $\mathrm{C}_{10} \mathrm{H}_{11} \mathrm{~N}_{7} \mathrm{NaO}_{3}$ [M + Na]: 300.0816; found: 300.0826.

4-(4-Methylpiperazin-1-yl)-2-(3-nitro-1H-1,2,4-triazol-1-yl)pyrimidine (1i)

Prepared according to GP2 using 1-methylpiperazine. Yellow solid, yield 66\%; mp 193-195 ${ }^{\circ} \mathrm{C}$ (decomp.). ${ }^{1} \mathrm{H}$ NMR $\left(400 \mathrm{MHz}, \mathrm{DMSO}-d_{6}\right) \delta 9.58(\mathrm{~s}, 1 \mathrm{H}), 8.31(\mathrm{~d}, J=6.2 \mathrm{~Hz}, 1 \mathrm{H}), 6.95(\mathrm{~d}, J=6.2 \mathrm{~Hz}, 1 \mathrm{H})$, $3.77(\mathrm{t}, J=5.1 \mathrm{~Hz}, 4 \mathrm{H}), 2.48-2.41(\mathrm{~m}, 5 \mathrm{H}), 2.27(\mathrm{~s}, 3 \mathrm{H}) .{ }^{13} \mathrm{C}$ NMR $\left(101 \mathrm{MHz}, \mathrm{DMSO}-d_{6}\right) \delta 163.2,162.3$, 157.2, 153.3, 146.8, 104.2, 54.5, 46.0, 43.9. HRMS-ESI $(\mathrm{m} / \mathrm{z})$ : calcd for $\mathrm{C}_{11} \mathrm{H}_{15} \mathrm{~N}_{8} \mathrm{O}_{2}[\mathrm{M}+\mathrm{H}]: 291.1312$; found: 291.1321 . 
N-Benzyl-2-(3-nitro-1H-1,2,4-triazol-1-yl)pyrimidin-4-amine (1j)

Prepared according to GP2 using phenylmethanamine. Beige solid, yield 39\%; mp 139-141 ${ }^{\circ} \mathrm{C}$. ${ }^{1} \mathrm{H}$ NMR (400 MHz, DMSO- $\left.d_{6}\right) \delta 9.49(\mathrm{~s}, 1 \mathrm{H}$, triazole $), 8.46(\mathrm{~s}, 1 \mathrm{H}, \mathrm{NH}), 8.19\left(\mathrm{~d}, J=6.0 \mathrm{~Hz}, 1 \mathrm{H}, \mathrm{H}_{\mathrm{Ar}}\right)$, 7.43-7.40 (m, 2H, $\left.\mathrm{H}_{\mathrm{Ar}}\right), 7.38-7.33\left(\mathrm{~m}, 2 \mathrm{H}, \mathrm{H}_{\mathrm{Ar}}\right), 7.30-7.24\left(\mathrm{~m}, 1 \mathrm{H}, \mathrm{H}_{\mathrm{Ar}}\right), 6.68\left(\mathrm{~d}, J=6.0 \mathrm{~Hz}, 1 \mathrm{H}, \mathrm{H}_{\mathrm{Ar}}\right), 4.66$ $\left(\mathrm{d}, J=6.0 \mathrm{~Hz}, 2 \mathrm{H}, \mathrm{CH}_{2}\right) .{ }^{13} \mathrm{C}$ NMR $\left(101 \mathrm{MHz}\right.$, DMSO- $\left.d_{6}\right) \delta 163.5,163.2,155.4,153.6,146.6,139.1,128.9$, 128.3, 127.6, 107.0, 44.0. HRMS-ESI $(m / z)$ : calcd for $\mathrm{C}_{13} \mathrm{H}_{11} \mathrm{~N}_{7} \mathrm{NaO}_{2}$ [M + Na]: 320.0866; found: 320.0858.

N-Isobutyl-2-(3-nitro-1H-1,2,4-triazol-1-yl)pyrimidin-4-amine (1k)

Prepared according to GP2 using 2-methylpropan-1-amine. Yellow solid, yield 32\%; mp 129-131 ${ }^{\circ} \mathrm{C}$. ${ }^{1} \mathrm{H}$ NMR $\left(400 \mathrm{MHz}, \mathrm{DMSO}-d_{6}\right) \delta 9.48\left(\mathrm{~s}, 1 \mathrm{H}\right.$, triazole), $8.15\left(\mathrm{~d}, J=5.7 \mathrm{~Hz}, 1 \mathrm{H}, \mathrm{H}_{\mathrm{Ar}}\right), 7.96(\mathrm{~s}, 1 \mathrm{H}, \mathrm{NH})$, $6.65\left(\mathrm{~d}, J=6.0 \mathrm{~Hz}, 1 \mathrm{H}, \mathrm{H}_{\mathrm{Ar}}\right), 3.26\left(\mathrm{~s}, 2 \mathrm{H}, \mathrm{CH}_{2}\right), 1.93(\mathrm{dp}, J=13.4,6.7 \mathrm{~Hz}, 1 \mathrm{H}, \mathrm{CH}), 0.97(\mathrm{~d}, J=6.7 \mathrm{~Hz}$, $\left.6 \mathrm{H}, \mathrm{CH}_{3}\right) .{ }^{13} \mathrm{C}$ NMR $\left(101 \mathrm{MHz}, \mathrm{DMSO}-d_{6}\right) \delta 163.8,163.2,155.0,153.6,146.5,106.9,47.9,28.2,20.6$. HRMS-ESI $(m / z)$ : calcd for $\mathrm{C}_{10} \mathrm{H}_{13} \mathrm{~N}_{7} \mathrm{NaO}_{2}[\mathrm{M}+\mathrm{Na}$ ]: 286.1023; found: 286.1015 .

2,2'-((2-(3-Nitro-1H-1,2,4-triazol-1-yl)pyrimidin-4-yl)azanediyl)bis(ethan-1-ol) (11)

Prepared according to GP2 using 2,2'-azanediylbis(ethan-1-ol). Green solid, yield 28\%; mp 163-165 ${ }^{\circ} \mathrm{C} .{ }^{1} \mathrm{H}$ NMR $\left(400 \mathrm{MHz}\right.$, DMSO- $\left.d_{6}\right) \delta 9.53\left(\mathrm{~s}, 1 \mathrm{H}\right.$, triazole), $8.25\left(\mathrm{~d}, J=6.2 \mathrm{~Hz}, 1 \mathrm{H}, \mathrm{H}_{\mathrm{Ar}}\right), 6.87$ $\left(\mathrm{d}, J=6.3 \mathrm{~Hz}, 1 \mathrm{H}, \mathrm{H}_{\mathrm{Ar}}\right), 4.61(\mathrm{~s}, 2 \mathrm{H}, \mathrm{OH}), 3.85-3.59\left(\mathrm{~m}, 8 \mathrm{H}, \mathrm{CH}_{2}\right) .{ }^{13} \mathrm{C}$ NMR $\left(101 \mathrm{MHz}, \mathrm{DMSO}-d_{6}\right) \delta$ 163.2, 162.7, 156.3, 153.1, 146.6, 104.7, 58.7, 51.8, 51.0. HRMS-ESI $(\mathrm{m} / \mathrm{z})$ : calcd for $\mathrm{C}_{10} \mathrm{H}_{14} \mathrm{~N}_{7} \mathrm{O}_{4}[\mathrm{M}+\mathrm{H}]$ : 296.1102; found: 296.1114 .

N-Cyclopropyl-2-(3-nitro-1H-1,2,4-triazol-1-yl)pyrimidin-4-amine (1n)

Prepared according to GP2 using cyclopropanamine. Yellow solid, yield 47\%; mp 193-195 ${ }^{\circ} \mathrm{C}$ (decomp.). ${ }^{1} \mathrm{H}$ NMR $\left(400 \mathrm{MHz}\right.$, DMSO- $\left.d_{6}\right) \delta 9.45$ (s, $1 \mathrm{H}$, triazole), 8.34-8.15 (m, 2H, NH, $\left.\mathrm{H}_{\mathrm{Ar}}\right), 6.74$ $\left(\mathrm{s}, 1 \mathrm{H}, \mathrm{H}_{\mathrm{Ar}}\right), 2.80(\mathrm{~s}, 1 \mathrm{H}, \mathrm{CH}), 0.84\left(\mathrm{td}, J=6.9,4.7 \mathrm{~Hz}, 2 \mathrm{H}, \mathrm{CH}_{2}\right), 0.58\left(\mathrm{dd}, J=4.1,2.4 \mathrm{~Hz}, 2 \mathrm{H}, \mathrm{CH}_{2}\right)$. ${ }^{13} \mathrm{C}$ NMR $\left(101 \mathrm{MHz}\right.$, DMSO- $\left.d_{6}\right) \delta 165.5,164.7,163.2,157.4,155.0,153.3,146.3,107.0,103.4,23.8,7.1,6.5$. HRMS-ESI $(\mathrm{m} / \mathrm{z})$ : calcd for $\mathrm{C}_{9} \mathrm{H}_{10} \mathrm{~N}_{7} \mathrm{O}_{2}[\mathrm{M}+\mathrm{H}]: 248.0890$; found: 248.0901 .

N-Isopropyl-2-(3-nitro-1H-1,2,4-triazol-1-yl)pyrimidin-4-amine (10)

Prepared according to GP2 using propan-2-amine. White solid, yield $43 \%$; mp $244-246{ }^{\circ} \mathrm{C} .{ }^{1} \mathrm{H}$ NMR $\left(400 \mathrm{MHz}, \mathrm{DMSO}-d_{6}\right) \delta 9.47\left(\mathrm{~s}, 1 \mathrm{H}\right.$, triazole), $8.14\left(\mathrm{~d}, J=6.0 \mathrm{~Hz}, 1 \mathrm{H}, \mathrm{H}_{\mathrm{Ar}}\right), 7.84(\mathrm{~d}, J=7.7 \mathrm{~Hz}, 1 \mathrm{H}$, $\mathrm{NH}), 6.59\left(\mathrm{~d}, J=6.1 \mathrm{~Hz}, 1 \mathrm{H}, \mathrm{H}_{\mathrm{Ar}}\right), 4.22(\mathrm{~s}, 1 \mathrm{H}, \mathrm{CH}), 1.24\left(\mathrm{~d}, J=6.5 \mathrm{~Hz}, 6 \mathrm{H}, \mathrm{CH}_{3}\right) .{ }^{13} \mathrm{C} \mathrm{NMR}(101 \mathrm{MHz}$, DMSO- $\left.d_{6}\right) \delta 163.2,162.7,154.9,153.7,146.5,106.9,42.2,22.6$. HRMS-ESI $(m / z)$ : calcd for $\mathrm{C}_{9} \mathrm{H}_{11} \mathrm{~N}_{7} \mathrm{NaO}_{2}$ [M + Na]: 272.0866; found: 272.0859 .

N-(3-(1H-Imidazol-1-yl)propyl)-2-(3-nitro-1H-1,2,4-triazol-1-yl)pyrimidin-4-amine (1p)

Prepared according to GP2 using 3-(1H-imidazol-1-yl)propan-1-amine. Yellow solid, yield 66\%; mp 198-200 ${ }^{\circ} \mathrm{C}$ (decomp.). ${ }^{1} \mathrm{H}$ NMR (400 MHz, DMSO- $\left.d_{6}\right) \delta 9.45(\mathrm{~s}, 1 \mathrm{H}$, triazole), $8.18(\mathrm{~d}, J=6.0 \mathrm{~Hz}, 1 \mathrm{H}$, $\left.\mathrm{H}_{\mathrm{Ar}}\right), 8.04(\mathrm{~s}, 1 \mathrm{H}, \mathrm{NH}), 7.61(\mathrm{~s}, 1 \mathrm{H}$, imidazole), $7.18(\mathrm{~d}, J=1.2 \mathrm{~Hz}, 1 \mathrm{H}$, imidazole), $6.90(\mathrm{~d}, J=1.1 \mathrm{~Hz}, 1 \mathrm{H}$, imidazole), $6.61\left(\mathrm{~d}, J=6.0 \mathrm{~Hz}, 1 \mathrm{H}, \mathrm{H}_{\mathrm{Ar}}\right), 4.09\left(\mathrm{t}, J=7.0 \mathrm{~Hz}, 2 \mathrm{H}, \mathrm{CH}_{2}\right), 3.40\left(\mathrm{~d}, J=7.1 \mathrm{~Hz}, 2 \mathrm{H}, \mathrm{CH}_{2}\right), 2.07$ $\left(\mathrm{p}, J=6.9 \mathrm{~Hz}, 2 \mathrm{H}, \mathrm{CH}_{2}\right) .{ }^{13} \mathrm{C}$ NMR $\left(101 \mathrm{MHz}, \mathrm{DMSO}-d_{6}\right) \delta 163.6,163.2,155.2,153.6,146.5,137.8,128.9$, 119.8, 107.1, 44.1, 37.8, 30.6. HRMS-ESI $(\mathrm{m} / \mathrm{z})$ : calcd for $\mathrm{C}_{12} \mathrm{H}_{14} \mathrm{~N}_{9} \mathrm{O}_{2}[\mathrm{M}+\mathrm{H}]$ : 316.1265; found: 316.1271 .

2-(3-Nitro-1H-1,2,4-triazol-1-yl)-4-(pyrrolidin-1-yl)pyrimidine (1q)

Prepared according to GP2 using pyrrolidine. Green solid, yield $44 \%$; mp $219-221^{\circ} \mathrm{C}$ (decomp.). ${ }^{1} \mathrm{H}$ NMR $\left(400 \mathrm{MHz}\right.$, DMSO- $\left.d_{6}\right) \delta 9.64\left(\mathrm{~s}, 1 \mathrm{H}\right.$, triazole), $8.61\left(\mathrm{~d}, J=5.2 \mathrm{~Hz}, 1 \mathrm{H}, \mathrm{H}_{\mathrm{Ar}}\right), 7.03(\mathrm{~d}, J=5.2 \mathrm{~Hz}$, $\left.1 \mathrm{H}, \mathrm{H}_{\mathrm{Ar}}\right), 3.69-3.54\left(\mathrm{~m}, 4 \mathrm{H}, \mathrm{CH}_{2}\right), 2.06-1.91\left(\mathrm{~m}, 4 \mathrm{H}, \mathrm{CH}_{2}\right) .{ }^{13} \mathrm{C}$ NMR $\left(126 \mathrm{MHz}, \mathrm{DMSO}-d_{6}\right) \delta 163.2$, 160.5, 156.0, 153.2, 146.6, 105.0, 47.1, 47.0, 25.5, 24.8. HRMS-ESI $(\mathrm{m} / \mathrm{z})$ : calcd for $\mathrm{C}_{10} \mathrm{H}_{12} \mathrm{~N}_{7} \mathrm{O}_{2}[\mathrm{M}+\mathrm{H}]$ : 262.1047; found: 262.1038 . 
2-(3-Nitro-1H-1,2,4-triazol-1-yl)-N-propylpyrimidin-4-amine (1r)

Prepared according to GP2 using propan-1-amine. Beige solid, yield $61 \%$; mp $127-129^{\circ} \mathrm{C}$. ${ }^{1} \mathrm{H}$ NMR (400 MHz, DMSO- $\left.d_{6}\right) \delta 9.47\left(\mathrm{~s}, 1 \mathrm{H}\right.$, triazole), $8.15\left(\mathrm{~d}, J=6.0 \mathrm{~Hz}, 1 \mathrm{H}, \mathrm{H}_{\mathrm{Ar}}\right), 7.95(\mathrm{~s}, 1 \mathrm{H}, \mathrm{NH}), 6.62(\mathrm{~d}$, $\left.J=6.0 \mathrm{~Hz}, 1 \mathrm{H}, \mathrm{H}_{\mathrm{Ar}}\right), 3.37\left(\mathrm{~d}, J=8.4 \mathrm{~Hz}, 2 \mathrm{H}, \mathrm{CH}_{2}\right), 1.63\left(\mathrm{q}, J=7.2 \mathrm{~Hz}, 2 \mathrm{H}, \mathrm{CH}_{2}\right), 0.96(\mathrm{t}, J=7.4 \mathrm{~Hz}$, $\left.3 \mathrm{H}, \mathrm{CH}_{3}\right) .{ }^{13} \mathrm{C}$ NMR $\left(101 \mathrm{MHz}, \mathrm{DMSO}-d_{6}\right) \delta 163.6,163.2,154.9,153.6,146.5,106.9,42.2,22.3,11.9$. HRMS-ESI $(\mathrm{m} / \mathrm{z})$ : calcd for $\mathrm{C}_{9} \mathrm{H}_{11} \mathrm{~N}_{7} \mathrm{NaO}_{2}$ [M + Na]: 272.0866; found: 272.0854 .

N-(4-Methoxybenzyl)-2-(3-nitro-1H-1,2,4-triazol-1-yl)pyrimidin-4-amine (1s)

Prepared according to GP2 using (4-methoxyphenyl)methanamine. Beige solid, yield 19\%; mp $147-149{ }^{\circ} \mathrm{C}$ (decomp.). ${ }^{1} \mathrm{H}$ NMR $\left(400 \mathrm{MHz}, \mathrm{DMSO}-d_{6}\right) \delta 9.51$ (s, $1 \mathrm{H}$, triazole), $8.18(\mathrm{~d}, J=6.0 \mathrm{~Hz}, 1 \mathrm{H}$, $\left.\mathrm{H}_{\mathrm{Ar}}\right), 7.39-7.30\left(\mathrm{~m}, 2 \mathrm{H}, \mathrm{H}_{\mathrm{Ar}}\right), 6.96-6.85\left(\mathrm{~m}, 2 \mathrm{H}, \mathrm{H}_{\mathrm{Ar}}\right), 6.66\left(\mathrm{~d}, J=6.0 \mathrm{~Hz}, 1 \mathrm{H}, \mathrm{H}_{\mathrm{Ar}}\right), 4.58(\mathrm{~d}, J=5.8 \mathrm{~Hz}$, $\left.2 \mathrm{H}, \mathrm{CH}_{2}\right), 3.76\left(\mathrm{~s}, 3 \mathrm{H}, \mathrm{CH}_{3}\right) .{ }^{13} \mathrm{C}$ NMR $\left(101 \mathrm{MHz}, \mathrm{DMSO}-d_{6}\right) \delta 163.3,163.2,158.9,155.3,153.6,146.6$, 130.9, 129.7, 114.3, 107.0, 55.5, 43.5. HRMS-ESI $(m / z)$ : calcd for $\mathrm{C}_{14} \mathrm{H}_{13} \mathrm{~N}_{7} \mathrm{NaO}_{3}[\mathrm{M}+\mathrm{Na}]$ : 350.0972; found: 350.0962 .

$N$-(4-Methoxyphenyl)-2-(3-nitro-1H-1,2,4-triazol-1-yl)pyrimidin-4-amine (1e)

A glass screw-capped vial containing a magnetic stir bar was charged with 2,4-bis(3-nitro-1H-1,2,4triazol-1-yl)pyrimidine (4) (0.98 mmol, $300 \mathrm{mg})$, 4-methoxyaniline (1.97 mmol, $242 \mathrm{mg})$ and DMSO $(3 \mathrm{~mL})$. The suspension was stirred at $100{ }^{\circ} \mathrm{C}$ for $24 \mathrm{~h}$. The reaction mixture was poured into water $(10 \mathrm{~mL})$ and cooled in a refrigerator. The resulting precipitate was filtered and purified by silica column chromatography with ethyl acetate- $n$-hexane (1:2) to afford a pure compound. Greenish solid, yield 45\%; mp 216-218 ${ }^{\circ} \mathrm{C} .{ }^{1} \mathrm{H}$ NMR $\left(400 \mathrm{MHz}, \mathrm{DMSO}-d_{6}\right) \delta 9.90(\mathrm{~s}, 1 \mathrm{H}, \mathrm{NH}), 9.44(\mathrm{~s}, 1 \mathrm{H}$, triazole), $8.32(\mathrm{~d}$, $\left.J=5.9 \mathrm{~Hz}, 1 \mathrm{H}, \mathrm{H}_{\mathrm{Ar}}\right), 7.62-7.48\left(\mathrm{~m}, 2 \mathrm{H}, \mathrm{H}_{\mathrm{Ar}}\right), 7.06-6.93\left(\mathrm{~m}, 2 \mathrm{H}, \mathrm{H}_{\mathrm{Ar}}\right), 6.80\left(\mathrm{~d}, J=6.0 \mathrm{~Hz}, 1 \mathrm{H}, \mathrm{H}_{\mathrm{Ar}}\right), 3.80$ (s, 3H, $\left.\mathrm{CH}_{3}\right) .{ }^{13} \mathrm{C}$ NMR $(126 \mathrm{MHz}$, DMSO-d 6 ) $\delta 163.2,161.7,156.4,153.4,146.5,131.9,122.7,114.8,107.7$, 55.7. HRMS-ESI $(\mathrm{m} / \mathrm{z})$ : calcd for $\mathrm{C}_{13} \mathrm{H}_{11} \mathrm{~N}_{7} \mathrm{NaO}_{3}[\mathrm{M}+\mathrm{Na}$ ]: 336.0816; found: 336.0826 .

2-(3-Nitro-1H-1,2,4-triazol-1-yl)-N-(p-tolyl)pyrimidin-4-amine (1m)

A glass screw-capped vial containing a magnetic stir bar was added to with 2,4-bis(3-nitro-1H-1,2,4triazol-1-yl)pyrimidine (4) $(0.98 \mathrm{mmol}, 300 \mathrm{mg})$, - -toluidine $(1.97 \mathrm{mmol}, 211 \mathrm{mg})$ and DMSO (3 mL). The suspension was stirred at $100{ }^{\circ} \mathrm{C}$ for $48 \mathrm{~h}$. The reaction mass was poured into water $(25 \mathrm{~mL})$ and extracted by ethyl acetate $(3 \times 20 \mathrm{~mL})$. The combined organic solutions were washed with water and brine, dried over $\mathrm{MgSO}_{4}$, absorbed on silica gel by concentration in vacuo and loaded on a chromatographic column. Elution with ethyl acetate- $n$-hexane (1:2) afforded the title compound. Yellow solid, yield 35\%; mp 199-201 ${ }^{\circ} \mathrm{C}$ (decomp.). ${ }^{1} \mathrm{H}$ NMR (400 MHz, DMSO- $\left.d_{6}\right) \delta 9.96(\mathrm{~s}, 1 \mathrm{H}, \mathrm{NH})$, $9.45(\mathrm{~s}, 1 \mathrm{H}$, triazole $), 8.35\left(\mathrm{~d}, J=5.9 \mathrm{~Hz}, 1 \mathrm{H}, \mathrm{H}_{\mathrm{Ar}}\right), 7.64-7.51\left(\mathrm{~m}, 2 \mathrm{H}, \mathrm{H}_{\mathrm{Ar}}\right), 7.23\left(\mathrm{~d}, J=8.1 \mathrm{~Hz}, 2 \mathrm{H}, \mathrm{H}_{\mathrm{Ar}}\right)$, $6.86\left(\mathrm{~d}, J=5.9 \mathrm{~Hz}, 1 \mathrm{H}, \mathrm{H}_{\mathrm{Ar}}\right), 2.33\left(\mathrm{~s}, 3 \mathrm{H}, \mathrm{CH}_{3}\right) .{ }^{13} \mathrm{C} \mathrm{NMR}\left(126 \mathrm{MHz}, \mathrm{DMSO}-d_{6}\right) \delta 163.2,161.7,156.7$, 153.4, 146.5, 136.4, 133.3, 130.0, 121.2, 107.8, 20.9. HRMS-ESI $(\mathrm{m} / \mathrm{z})$ : calcd for $\mathrm{C}_{13} \mathrm{H}_{11} \mathrm{~N}_{7} \mathrm{NaO}_{2}[\mathrm{M}+\mathrm{Na}]$ : 320.0866; found: 320.0874 .

\subsubsection{Preparation of 2-chloro-4-(3-nitro-1H-1,2,4-triazol-1-yl)pyrimidine (5)}

A two-neck round-bottomed flask equipped with a magnetic stir bar was charged with 2,4-dichloropyrimidine (1.96 g, $13.4 \mathrm{mmol}$ ) and dry DMF (5 mL). Potassium 3-nitro-1,2,4-triazol-1-ide $(3,1 \mathrm{~g}, 6.57 \mathrm{mmol})$ was dissolved in dry DMF $(20 \mathrm{~mL})$ and was added slowly via a syringe pump to a vigorously stirred solution of 2,4-dichloropyrimidine at $80^{\circ} \mathrm{C}$ over $8 \mathrm{~h}$. The resulting mixture was left under stirring for $16 \mathrm{~h}$ at $80^{\circ} \mathrm{C}$. After cooling to room temperature, the reaction mixture was concentrated under reduced pressure. The residue was dissolved in ethyl acetate and passed through a short plug of silica eluting with $50 \mathrm{~mL}$ more of ethyl acetate. The eluted solution was concentrated in vacuo and the crude product was purified by column chromatography on silica gel (ethyl acetate- $n$-hexane, 1:2) to give $634 \mathrm{mg}$ (43\%) of the title compound as a white solid, $\mathrm{mp} 143-145{ }^{\circ} \mathrm{C}$ 
(934 mg of starting 2,4-dichloropyrimidine was recovered by the same purification). ${ }^{1} \mathrm{H} \mathrm{NMR}(400 \mathrm{MHz}$, DMSO- $\left.d_{6}\right) \delta 9.87(\mathrm{~s}, 1 \mathrm{H}$, triazole $), 9.07\left(\mathrm{~d}, J=5.5 \mathrm{~Hz}, 1 \mathrm{H}, \mathrm{H}_{\mathrm{Ar}}\right), 8.08\left(\mathrm{~d}, J=5.4 \mathrm{~Hz}, 1 \mathrm{H}, \mathrm{H}_{\mathrm{Ar}}\right) .{ }^{13} \mathrm{C} \mathrm{NMR}$ $\left(101 \mathrm{MHz}, \mathrm{DMSO}-d_{6}\right) \delta 164.5,163.6,159.9,156.3,146.8,109.8$. HRMS-ESI $(m / z)$ : calcd for $\mathrm{C}_{6} \mathrm{H}_{4} \mathrm{ClN}_{6} \mathrm{O}_{2}$ [M+ H]: 227.0079; found: 227.0083.

\subsubsection{General Procedure 1 (GP1) for Preparation of Compounds 1a-d, 1f-1 and 1n-s}

A glass screw-capped vial containing a magnetic stir bar was charged with 2-chloro-4-(3-nitro- $1 \mathrm{H}$ 1,2,4-triazol-1-yl)pyrimidine (5) $(0.44 \mathrm{mmol}, 100 \mathrm{mg})$, amine $(1.32 \mathrm{mmol})$ and acetonitrile $(1 \mathrm{~mL})$. The reaction mixture was stirred at room temerature. After completion of the reaction (TLC analysis), the solvent was removed in vacuo. The resulting solid was suspended in water $(5 \mathrm{~mL})$ and the suspension was cooled in the refrigerator. After $2 \mathrm{~h}$, the thick precipitate was filtered off, air-dried and additionally cristallyzed from $96 \%$ ethanol to afford the product.

2-((4-(3-Nitro-1H-1,2,4-triazol-1-yl)pyrimidin-2-yl)amino)ethan-1-ol (2a)

Prepared according to GP1 using 2-aminoethan-1-ol. Greenish solid, yield 39\%; mp 200-202 ${ }^{\circ} \mathrm{C}$ (decomp.). 1H NMR (400 MHz, DMSO- $\left.d_{6}\right) \delta 9.55\left(\mathrm{~s}, 1 \mathrm{H}\right.$, triazole), $8.55\left(\mathrm{~d}, J=5.1 \mathrm{~Hz}, 1 \mathrm{H}, \mathrm{H}_{\mathrm{Ar}}\right), 7.37(\mathrm{~s}$, $\left.J=7.0 \mathrm{~Hz},{ }^{1} \mathrm{H}, \mathrm{NH}\right), 7.03\left(\mathrm{~d}, J=5.2 \mathrm{~Hz}, 1 \mathrm{H}, \mathrm{H}_{\mathrm{Ar}}\right), 4.44(\mathrm{~s}, 1 \mathrm{H}, \mathrm{OH}), 3.61\left(\mathrm{t}, J=6.1 \mathrm{~Hz}, 2 \mathrm{H}, \mathrm{CH}_{2}\right), 3.50(\mathrm{q}$, $\left.J=5.9 \mathrm{~Hz}, 2 \mathrm{H}, \mathrm{CH}_{2}\right) .{ }^{13} \mathrm{C}$ NMR $\left(126 \mathrm{MHz}, \mathrm{DMSO}-d_{6}\right) \delta 163.3,162.6,162.2,155.0,145.4,97.1,59.9,44.0$. HRMS-ESI $(m / z)$ : calcd for $\mathrm{C}_{8} \mathrm{H}_{10} \mathrm{~N}_{7} \mathrm{O}_{3}[\mathrm{M}+\mathrm{H}]$ : 252.0840; found: 252.0848.

N,N-Dimethyl-4-(3-nitro-1H-1,2,4-triazol-1-yl)pyrimidin-2-amine (2b)

Prepared according to GP1 using dimethylamine. Greenish solid, yield 54\%; mp $167-169{ }^{\circ} \mathrm{C}$ (decomp.). ${ }^{1} \mathrm{H}$ NMR (400 MHz, DMSO- $\left.d_{6}\right) \delta 9.69\left(\mathrm{~s}, 1 \mathrm{H}\right.$, triazole), $8.61\left(\mathrm{~d}, J=5.2 \mathrm{~Hz}, 1 \mathrm{H}, \mathrm{H}_{\mathrm{Ar}}\right), 7.01(\mathrm{~d}$, $\left.J=5.2 \mathrm{~Hz}, 1 \mathrm{H}, \mathrm{H}_{\mathrm{Ar}}\right), 3.23\left(\mathrm{~s}, 6 \mathrm{H}, \mathrm{CH}_{3}\right) .{ }^{13} \mathrm{C} \mathrm{NMR}\left(126 \mathrm{MHz}, \mathrm{DMSO}-d_{6}\right) \delta 163.3,162.4,161.6,154.9,96.5$, 37.1. HRMS-ESI $(\mathrm{m} / \mathrm{z})$ : calcd for $\mathrm{C}_{8} \mathrm{H}_{10} \mathrm{~N}_{7} \mathrm{O}_{2}[\mathrm{M}+\mathrm{H}]$ : 236.0890 ; found: 236.0881 .

N-Methyl-4-(3-nitro-1H-1,2,4-triazol-1-yl)pyrimidin-2-amine (2c)

Prepared according to GP1 using methanamine. Greenish solid, yield $62 \%$; mp $238-240{ }^{\circ} \mathrm{C}$ (decomp.). ${ }^{1} \mathrm{H}$ NMR $\left(400 \mathrm{MHz}, \mathrm{DMSO}-d_{6}\right) \delta 9.57\left(\mathrm{~s}, 1 \mathrm{H}\right.$, triazole), $8.56\left(\mathrm{~d}, J=5.2 \mathrm{~Hz}, 1 \mathrm{H}, \mathrm{H}_{\mathrm{Ar}}\right), 7.47(\mathrm{~s}$, $1 \mathrm{H}, \mathrm{NH}), 7.03\left(\mathrm{~d}, J=5.1 \mathrm{~Hz}, 1 \mathrm{H}, \mathrm{H}_{\mathrm{Ar}}\right), 2.94\left(\mathrm{~d}, J=4.8 \mathrm{~Hz}, 3 \mathrm{H}, \mathrm{CH}_{3}\right) .{ }^{13} \mathrm{C} \mathrm{NMR}(126 \mathrm{MHz}, \mathrm{DMSO}) \delta$ 163.3, 162.9, 162.6, 155.1, 145.5, 96.9, 28.2. HRMS-ESI $(\mathrm{m} / \mathrm{z})$ : calcd for $\mathrm{C}_{7} \mathrm{H}_{8} \mathrm{~N}_{7} \mathrm{O}_{2}[\mathrm{M}+\mathrm{H}]: 222.0734$; found: 222.0742 .

$N$-Benzyl-N-methyl-4-(3-nitro-1H-1,2,4-triazol-1-yl)pyrimidin-2-amine (2d)

Prepared according to GP1 using N-methyl-1-phenylmethanamine. Greenish solid, yield 23\%; mp 145-147 ${ }^{\circ} \mathrm{C} .{ }^{1} \mathrm{H}$ NMR $\left(400 \mathrm{MHz}\right.$, DMSO- $\left.d_{6}\right) \delta 9.70\left(\mathrm{~s}, 1 \mathrm{H}\right.$, triazole), $8.66\left(\mathrm{~d}, J=5.2 \mathrm{~Hz}, 1 \mathrm{H}, \mathrm{H}_{\mathrm{Ar}}\right), 7.39-7.24$ $\left(\mathrm{m}, 5 \mathrm{H}, \mathrm{H}_{\mathrm{Ar}}\right), 7.09\left(\mathrm{~d}, J=5.2 \mathrm{~Hz}, 1 \mathrm{H}, \mathrm{H}_{\mathrm{Ar}}\right), 4.98\left(\mathrm{~s}, 2 \mathrm{H}, \mathrm{CH}_{2}\right), 3.21\left(\mathrm{~s}, 3 \mathrm{H}, \mathrm{CH}_{3}\right) .{ }^{13} \mathrm{C} \mathrm{NMR}(126 \mathrm{MHz}$, DMSO- $\left.d_{6}\right) \delta 163.3,162.7,161.6,155.0,145.7,138.3,129.0,128.1,127.6,97.2,52.2,35.4$. HRMS-ESI $(\mathrm{m} / \mathrm{z})$ : calcd for $\mathrm{C}_{14} \mathrm{H}_{13} \mathrm{~N}_{7} \mathrm{NaO}_{2}$ [M + Na]: 334.1023; found: 334.1025.

3-((4-(3-Nitro-1H-1,2,4-triazol-1-yl)pyrimidin-2-yl)amino)propan-1-ol (2f)

Prepared according to GP1 using 3-aminopropan-1-ol. Greenish solid, yield 58\%; mp 178-180 ${ }^{\circ} \mathrm{C}$. ${ }^{1} \mathrm{H}$ NMR $\left(400 \mathrm{MHz}, \mathrm{DMSO}-d_{6}\right) \delta 9.54\left(\mathrm{~s}, 1 \mathrm{H}\right.$, triazole), $8.55\left(\mathrm{~d}, J=5.2 \mathrm{~Hz}, 1 \mathrm{H}, \mathrm{H}_{\mathrm{Ar}}\right), 7.49(\mathrm{~s}, 1 \mathrm{H}, \mathrm{NH})$, $7.01\left(\mathrm{~d}, J=5.2 \mathrm{~Hz}, 1 \mathrm{H}, \mathrm{H}_{\mathrm{Ar}}\right), 4.24(\mathrm{t}, J=5.2 \mathrm{~Hz}, 1 \mathrm{H}, \mathrm{OH}), 3.55\left(\mathrm{td}, J=6.2,5.2 \mathrm{~Hz}, 2 \mathrm{H}, \mathrm{CH}_{2}\right), 3.51-3.43$ $\left(\mathrm{m}, 2 \mathrm{H}, \mathrm{CH}_{2}\right), 1.78\left(\mathrm{~h}, J=6.8 \mathrm{~Hz}, 2 \mathrm{H}, \mathrm{CH}_{2}\right) .{ }^{13} \mathrm{C} \mathrm{NMR}\left(101 \mathrm{MHz}, \mathrm{DMSO}-d_{6}\right) \delta 163.3,162.6,162.2,145.4$, 96.9, 59.1, 38.5, 32.5. HRMS-ESI $(\mathrm{m} / \mathrm{z})$ : calcd for $\mathrm{C}_{9} \mathrm{H}_{12} \mathrm{~N}_{7} \mathrm{O}_{3}[\mathrm{M}+\mathrm{H}]$ : 266.0996; found: 266.1002 . 
N-Ethyl-4-(3-nitro-1H-1,2,4-triazol-1-yl)pyrimidin-2-amine (2g)

Prepared according to GP1 using ethanamine. Green solid, yield $75 \%$; mp $229-231{ }^{\circ} \mathrm{C}$ (decomp.). ${ }^{1} \mathrm{H}$ NMR (400 MHz, DMSO- $\left.d_{6}\right) \delta 9.53\left(\mathrm{~s}, 1 \mathrm{H}\right.$, triazole), $8.55\left(\mathrm{~d}, J=5.2 \mathrm{~Hz}, 1 \mathrm{H}, \mathrm{H}_{\mathrm{Ar}}\right), 7.52(\mathrm{~s}, 1 \mathrm{H}, \mathrm{NH})$, $7.01\left(\mathrm{~d}, J=5.2 \mathrm{~Hz}, 1 \mathrm{H}, \mathrm{H}_{\mathrm{Ar}}\right), 3.44\left(\mathrm{qd}, J=7.1,5.7 \mathrm{~Hz}, 2 \mathrm{H}, \mathrm{CH}_{2}\right), 1.20\left(\mathrm{t}, J=7.2 \mathrm{~Hz}, 3 \mathrm{H}, \mathrm{CH}_{3}\right) .{ }^{13} \mathrm{C} \mathrm{NMR}$ $\left(101 \mathrm{MHz}, \mathrm{DMSO}-d_{6}\right) \delta 163.3,162.6,162.3,155.1,145.4,97.0,36.0,14.9$. HRMS-ESI $(\mathrm{m} / \mathrm{z})$ : calcd for $\mathrm{C}_{8} \mathrm{H}_{10} \mathrm{~N}_{7} \mathrm{O}_{2}[\mathrm{M}+\mathrm{H}]: 236.0890$; found: 236.0897 .

4-(4-(3-Nitro-1H-1,2,4-triazol-1-yl)pyrimidin-2-yl)morpholine (2h)

Prepared according to GP1 using morpholine. Yellow solid, yield 83\%; mp 201-203 ${ }^{\circ} \mathrm{C}$ (decomp.). ${ }^{1} \mathrm{H}$ NMR (400 MHz, DMSO- $\left.d_{6}\right) \delta 9.77\left(\mathrm{~s}, 1 \mathrm{H}\right.$, triazole), $8.66\left(\mathrm{~d}, J=5.2 \mathrm{~Hz}, 1 \mathrm{H}, \mathrm{H}_{\mathrm{Ar}}\right), 7.10(\mathrm{~d}, J=5.2 \mathrm{~Hz}$, $\left.1 \mathrm{H}, \mathrm{H}_{\mathrm{Ar}}\right), 3.87\left(\mathrm{dd}, J=5.7,4.1 \mathrm{~Hz}, 4 \mathrm{H}, \mathrm{CH}_{2}\right), 3.73\left(\mathrm{dd}, J=5.7,4.1 \mathrm{~Hz}, 4 \mathrm{H}, \mathrm{CH}_{2}\right) .{ }^{13} \mathrm{C} \mathrm{NMR}(101 \mathrm{MHz}$, DMSO- $\left.d_{6}\right) \delta 163.3,162.7,161.0,155.0,145.8,97.7,66.4,44.4$. HRMS-ESI $(m / z)$ : calcd for $\mathrm{C}_{10} \mathrm{H}_{11} \mathrm{~N}_{7} \mathrm{NaO}_{3}$ [M + Na]: 300.0816; found: 300.0828.

2-(4-Methylpiperazin-1-yl)-4-(3-nitro-1H-1,2,4-triazol-1-yl)pyrimidine (2i)

Prepared according to GP1 using 1-methylpiperazine. Greenish solid, yield 76\%; mp 210-212 ${ }^{\circ} \mathrm{C}$ (decomp.). ${ }^{1} \mathrm{H}$ NMR $\left(400 \mathrm{MHz}\right.$, DMSO- $\left.d_{6}\right) \delta 9.75\left(\mathrm{~s}, 1 \mathrm{H}\right.$, triazole), $8.63\left(\mathrm{~d}, J=5.2 \mathrm{~Hz}, 1 \mathrm{H}, \mathrm{H}_{\mathrm{ar}}\right), 7.06$ $\left(\mathrm{d}, J=5.2 \mathrm{~Hz}, 1 \mathrm{H}, \mathrm{H}_{\mathrm{Ar}}\right), 3.92-3.83\left(\mathrm{~m}, 4 \mathrm{H}, \mathrm{CH}_{2}\right), 2.47-2.40\left(\mathrm{~m}, 4 \mathrm{H}, \mathrm{CH}_{2}\right), 2.27\left(\mathrm{~s}, 3 \mathrm{H}, \mathrm{CH}_{3}\right) .{ }^{13} \mathrm{C} \mathrm{NMR}$ $\left(101 \mathrm{MHz}\right.$, DMSO- $\left.d_{6}\right) \delta 163.3,162.7,160.9,155.1,145.8,97.4,54.8,46.2,43.9$. HRMS-ESI $(\mathrm{m} / \mathrm{z})$ : calcd for $\mathrm{C}_{11} \mathrm{H}_{15} \mathrm{~N}_{8} \mathrm{O}_{2}[\mathrm{M}+\mathrm{H}]$ : 291.1312; found: 291.1319.

N-Benzyl-4-(3-nitro-1H-1,2,4-triazol-1-yl)pyrimidin-2-amine (2j)

Prepared according to GP1 using benzylamine. White solid, yield $81 \%$; $\mathrm{mp} 212-214{ }^{\circ} \mathrm{C}$ (decomp.). ${ }^{1} \mathrm{H}$ NMR $\left(400 \mathrm{MHz}\right.$, DMSO- $\left.d_{6}\right) \delta 9.52(\mathrm{~s}, 1 \mathrm{H}$, triazole $), 8.57\left(\mathrm{~d}, J=5.1 \mathrm{~Hz}, 1 \mathrm{H}, \mathrm{H}_{\mathrm{Ar}}\right), 8.11(\mathrm{~s}, 1 \mathrm{H}, \mathrm{NH}), 7.41$ $\left(\mathrm{d}, J=7.0 \mathrm{~Hz}, 2 \mathrm{H}, \mathrm{H}_{\mathrm{Ar}}\right), 7.36-7.29\left(\mathrm{~m}, 2 \mathrm{H}, \mathrm{H}_{\mathrm{Ar}}\right), 7.27-7.20\left(\mathrm{~m}, 1 \mathrm{H}, \mathrm{H}_{\mathrm{Ar}}\right), 7.05\left(\mathrm{~d}, J=5.1 \mathrm{~Hz}, 1 \mathrm{H}, \mathrm{H}_{\mathrm{Ar}}\right), 4.64$ $\left(\mathrm{d}, J=6.3 \mathrm{~Hz}, 2 \mathrm{H}, \mathrm{CH}_{2}\right) .{ }^{13} \mathrm{C}$ NMR $\left(101 \mathrm{MHz}, \mathrm{DMSO}-d_{6}\right) \delta 163.3,162.9,162.3,145.3,140.2,128.7,128.1$, 127.5, 127.2, 97.4, 44.6. HRMS-ESI $(\mathrm{m} / \mathrm{z})$ : calcd for $\mathrm{C}_{13} \mathrm{H}_{12} \mathrm{~N}_{7} \mathrm{O}_{2}$ [M + H]: 296.1047; found: 296.1050.

N-Isobutyl-4-(3-nitro-1H-1,2,4-triazol-1-yl)pyrimidin-2-amine (2k)

Prepared according to GP1 using 2-methylpropan-1-amine. Greenish solid, yield 44\%; mp 149-151 ${ }^{\circ} \mathrm{C} .{ }^{1} \mathrm{H}$ NMR $\left(400 \mathrm{MHz}\right.$, DMSO-d 6 ) $\delta 9.53\left(\mathrm{~s}, 1 \mathrm{H}\right.$, triazole), $8.54\left(\mathrm{~d}, J=5.1 \mathrm{~Hz}, 1 \mathrm{H}, \mathrm{H}_{\mathrm{Ar}}\right), 7.57(\mathrm{~s}$, $1 \mathrm{H}, \mathrm{NH}), 7.01\left(\mathrm{~d}, J=5.2 \mathrm{~Hz}, 1 \mathrm{H}, \mathrm{H}_{\mathrm{Ar}}\right), 3.25\left(\mathrm{dd}, J=6.8,6.0 \mathrm{~Hz}, 2 \mathrm{H}, \mathrm{CH}_{2}\right), 1.94(\mathrm{dt}, J=13.4,6.7 \mathrm{~Hz}, 1 \mathrm{H}$, $\mathrm{CH}), 0.95\left(\mathrm{~d}, J=6.7 \mathrm{~Hz}, 6 \mathrm{H}, \mathrm{CH}_{3}\right) .{ }^{13} \mathrm{C} \mathrm{NMR}\left(101 \mathrm{MHz}, \mathrm{DMSO}-d_{6}\right) \delta 163.3,162.6,155.0,145.4,145.0$, 96.9, 48.6, 28.3, 20.6. HRMS-ESI $(m / z)$ : calcd for $\mathrm{C}_{10} \mathrm{H}_{14} \mathrm{~N}_{7} \mathrm{O}_{2}$ [M + H]: 264.1203; found: 264.1212.

2,2' -((4-(3-nitro-1H-1,2,4-triazol-1-yl)pyrimidin-2-yl)azanediyl)bis(ethan-1-ol) (21)

Prepared according to GP1 using 2,2'-azanediylbis(ethan-1-ol). Yellow solid, yield 71\%; mp 172-174 ${ }^{\circ} \mathrm{C} .{ }^{1} \mathrm{H}$ NMR $\left(400 \mathrm{MHz}, \mathrm{DMSO}-d_{6}\right) \delta 9.65\left(\mathrm{~s}, 1 \mathrm{H}\right.$, triazole), $8.61\left(\mathrm{~d}, J=5.2 \mathrm{~Hz}, 1 \mathrm{H}, \mathrm{H}_{\mathrm{Ar}}\right), 7.03$ $\left(\mathrm{d}, J=5.1 \mathrm{~Hz}, 1 \mathrm{H}, \mathrm{H}_{\mathrm{Ar}}\right), 4.52(\mathrm{~s}, 2 \mathrm{H}, \mathrm{OH}), 3.80\left(\mathrm{t}, J=6.2 \mathrm{~Hz}, 4 \mathrm{H}, \mathrm{CH}_{2}\right), 3.69\left(\mathrm{~d}, J=6.2 \mathrm{~Hz}, 4 \mathrm{H}, \mathrm{CH}_{2}\right)$. ${ }^{13} \mathrm{C}$ NMR (126 MHz, DMSO- $\left.d_{6}\right) \delta 163.3,162.4,161.1,154.9,145.5,96.8,58.9,51.5$, 51.4. HRMS-ESI $(\mathrm{m} / \mathrm{z})$ : calcd for $\mathrm{C}_{10} \mathrm{H}_{14} \mathrm{~N}_{7} \mathrm{O}_{4}[\mathrm{M}+\mathrm{H}]$ : 296.1102; found: 296.1114 .

N-cyclopropyl-4-(3-nitro-1H-1,2,4-triazol-1-yl)pyrimidin-2-amine (2n)

Prepared according to GP1 using cyclopropylamine. Greenish solid, yield 49\%; mp 207-209 ${ }^{\circ} \mathrm{C}$. ${ }^{1} \mathrm{H}$ NMR $\left(400 \mathrm{MHz}\right.$, DMSO- $\left.d_{6}\right) \delta 9.51\left(\mathrm{~s}, 1 \mathrm{H}\right.$, triazole), $8.59\left(\mathrm{~d}, J=5.2 \mathrm{~Hz}, 1 \mathrm{H}, \mathrm{H}_{\mathrm{Ar}}\right), 7.75(\mathrm{~d}, J=3.9 \mathrm{~Hz}$, $1 \mathrm{H}, \mathrm{NH}), 7.08\left(\mathrm{~d}, J=5.2 \mathrm{~Hz}, 1 \mathrm{H}, \mathrm{H}_{\mathrm{Ar}}\right), 2.91(\mathrm{td}, J=7.2,3.6 \mathrm{~Hz}, 1 \mathrm{H}, \mathrm{CH}), 0.78(\mathrm{td}, J=7.0,4.7 \mathrm{~Hz}, 2 \mathrm{H}$, $\left.\mathrm{CH}_{2}\right), 0.61-0.54\left(\mathrm{~m}, 2 \mathrm{H}, \mathrm{CH}_{2}\right) .{ }^{13} \mathrm{C}$ NMR $\left(101 \mathrm{MHz}, \mathrm{DMSO}-d_{6}\right) \delta 163.4,163.3,162.5,155.0,145.1,97.8$, 24.4, 6.6. HRMS-ESI $(\mathrm{m} / \mathrm{z})$ : calcd for $\mathrm{C}_{9} \mathrm{H}_{10} \mathrm{~N}_{7} \mathrm{O}_{2}$ [M + H]: 248.0890; found: 248.0901 . 
N-Isopropyl-4-(3-nitro-1H-1,2,4-triazol-1-yl)pyrimidin-2-amine (2o)

Prepared according to GP1 using propan-2-amine. Green solid, yield 59\%; mp 193-195 ${ }^{\circ} \mathrm{C}$ (decomp.). ${ }^{1} \mathrm{H}$ NMR (400 MHz, DMSO- $\left.d_{6}\right) \delta 9.51\left(\mathrm{~s}, 1 \mathrm{H}\right.$, triazole), $8.55\left(\mathrm{~d}, J=5.1 \mathrm{~Hz}, 1 \mathrm{H}, \mathrm{H}_{\mathrm{Ar}}\right), 7.39(\mathrm{~d}$, $J=7.9 \mathrm{~Hz}, 1 \mathrm{H}, \mathrm{NH}), 7.00\left(\mathrm{~d}, J=5.2 \mathrm{~Hz}, 1 \mathrm{H}, \mathrm{H}_{\mathrm{Ar}}\right), 4.20(\mathrm{dp}, J=7.9,6.5 \mathrm{~Hz}, 1 \mathrm{H}, \mathrm{CH}), 1.23(\mathrm{~d}, J=6.5 \mathrm{~Hz}$, $\left.6 \mathrm{H}, \mathrm{CH}_{3}\right) .{ }^{13} \mathrm{C}$ NMR $\left(101 \mathrm{MHz}\right.$, DMSO- $\left.d_{6}\right) \delta 163.3,162.6,161.6,155.1,145.3,96.9,42.7,22.6$. HRMS-ESI $(m / z)$ : calcd for $\mathrm{C}_{9} \mathrm{H}_{12} \mathrm{~N}_{7} \mathrm{O}_{2}$ [M $\left.+\mathrm{H}\right]$ : 250.1047; found: 250.1056 .

N-(3-(1H-Imidazol-1-yl)propyl)-4-(3-nitro-1H-1,2,4-triazol-1-yl)pyrimidin-2-amine (2p)

Prepared according to GP1 using 3-(1H-imidazol-1-yl)propan-1-amine. Greenish solid, yield 26\%; mp $196-198{ }^{\circ} \mathrm{C} .{ }^{1} \mathrm{H}$ NMR $\left(400 \mathrm{MHz}, \mathrm{DMSO}-d_{6}\right) \delta 9.48(\mathrm{~s}, 1 \mathrm{H}$, triazole $), 8.56\left(\mathrm{~d}, J=5.2 \mathrm{~Hz}, 1 \mathrm{H}, \mathrm{H}_{\mathrm{Ar}}\right)$, $7.69(\mathrm{t}, J=5.9 \mathrm{~Hz}, 1 \mathrm{H}, \mathrm{NH}), 7.63(\mathrm{~d}, J=1.2 \mathrm{~Hz}, 1 \mathrm{H}$, imidazole), $7.17(\mathrm{~d}, J=1.3 \mathrm{~Hz}, 1 \mathrm{H}$, imidazole), $7.04\left(\mathrm{~d}, J=5.2 \mathrm{~Hz}, 1 \mathrm{H}, \mathrm{H}_{\mathrm{Ar}}\right), 6.91(\mathrm{~d}, J=1.1 \mathrm{~Hz}, 1 \mathrm{H}$, imidazole $), 4.09\left(\mathrm{t}, J=7.0 \mathrm{~Hz}, 2 \mathrm{H}, \mathrm{CH}_{2}\right), 3.40(\mathrm{q}$, $\left.J=6.6 \mathrm{~Hz}, 2 \mathrm{H}, \mathrm{CH}_{2}\right), 2.06\left(\mathrm{p}, J=6.9 \mathrm{~Hz}, 2 \mathrm{H}, \mathrm{CH}_{2}\right) .{ }^{13} \mathrm{C}$ NMR $\left(126 \mathrm{MHz}, \mathrm{DMSO}-d_{6}\right) \delta 163.3,162.7,162.4$, 155.0, 145.3, 137.8, 128.8, 119.8, 97.2, 56.5, 44.2, 38.3, 30.8, 19.0. HRMS-ESI $(\mathrm{m} / \mathrm{z})$ : calcd for $\mathrm{C}_{12} \mathrm{H}_{14} \mathrm{~N}_{9} \mathrm{O}_{2}$ $[\mathrm{M}+\mathrm{H}]: 316.1265$; found: 316.1270 .

4-(3-Nitro-1H-1,2,4-triazol-1-yl)-2-(pyrrolidin-1-yl)pyrimidine (2q)

Prepared according to GP1 using pyrrolidine. White solid, yield $40 \% ; \mathrm{mp} 188-190{ }^{\circ} \mathrm{C}$ (decomp.). ${ }^{1} \mathrm{H}$ NMR (400 MHz, DMSO- $\left.d_{6}\right) \delta 9.64\left(\mathrm{~s}, 1 \mathrm{H}\right.$, triazole), $8.61\left(\mathrm{~d}, J=5.2 \mathrm{~Hz}, 1 \mathrm{H}, \mathrm{H}_{\mathrm{Ar}}\right), 7.02(\mathrm{~d}, J=5.2 \mathrm{~Hz}$, $\left.1 \mathrm{H}, \mathrm{H}_{\mathrm{Ar}}\right), 3.67-3.57\left(\mathrm{~m}, 4 \mathrm{H}, \mathrm{CH}_{2}\right), 2.06-1.94\left(\mathrm{~m}, 4 \mathrm{H}, \mathrm{CH}_{2}\right) .{ }^{13} \mathrm{C} \mathrm{NMR}\left(101 \mathrm{MHz}, \mathrm{DMSO}-d_{6}\right) \delta 163.3$, 162.4, 159.6, 154.8, 145.4, 96.5, 47.0, 25.4, 25.2. HRMS-ESI $(\mathrm{m} / \mathrm{z})$ : calcd for $\mathrm{C}_{10} \mathrm{H}_{12} \mathrm{~N}_{7} \mathrm{O}_{2}[\mathrm{M}+\mathrm{H}]$ : 262.1047; found: 262.1053 .

4-(3-Nitro-1H-1,2,4-triazol-1-yl)-N-propylpyrimidin-2-amine (2r)

Prepared according to GP1 using propan-1-amine. White solid, yield $49 \%$; mp $175-177{ }^{\circ} \mathrm{C}$ (decomp.). ${ }^{1} \mathrm{H}$ NMR $\left(400 \mathrm{MHz}, \mathrm{DMSO}-d_{6}\right) \delta 9.53\left(\mathrm{~s}, 1 \mathrm{H}\right.$, triazole), $8.55\left(\mathrm{~d}, J=5.2 \mathrm{~Hz}, 1 \mathrm{H}, \mathrm{H}_{\mathrm{Ar}}\right), 7.54(\mathrm{~s}$, $1 \mathrm{H}, \mathrm{NH}), 7.01\left(\mathrm{~d}, J=5.1 \mathrm{~Hz}, 1 \mathrm{H}, \mathrm{H}_{\mathrm{Ar}}\right), 3.44-3.32\left(\mathrm{~m}, 2 \mathrm{H}, \mathrm{CH}_{2}\right), 1.62\left(\mathrm{~h}, J=7.3 \mathrm{~Hz}, 2 \mathrm{H}, \mathrm{CH}_{2}\right), 0.95(\mathrm{t}$, $\left.J=7.4 \mathrm{~Hz}, 3 \mathrm{H}, \mathrm{CH}_{3}\right) .{ }^{13} \mathrm{C}$ NMR $\left(101 \mathrm{MHz}, \mathrm{DMSO}-d_{6}\right) \delta 163.3,162.5,162.2,155.0,145.4,96.9,42.9,22.5$, 11.9. HRMS-ESI $(m / z)$ : calcd for $\mathrm{C}_{9} \mathrm{H}_{12} \mathrm{~N}_{7} \mathrm{O}_{2}[\mathrm{M}+\mathrm{H}]$ : 250.1047; found: 250.1058 .

N-(4-Methoxybenzyl)-4-(3-nitro-1H-1,2,4-triazol-1-yl)pyrimidin-2-amine (2s)

Prepared according to GP1 using (4-methoxyphenyl)methanamine. Greenish solid, yield $46 \%$; $\mathrm{pp}$ 248-250 ${ }^{\circ} \mathrm{C}$ (decomp.). ${ }^{1} \mathrm{H}$ NMR (400 MHz, DMSO- $\left.d_{6}\right) \delta 9.54(\mathrm{~s}, 1 \mathrm{H}$, triazole), $8.57(\mathrm{~d}, J=5.2 \mathrm{~Hz}, 1 \mathrm{H}$, $\left.\mathrm{H}_{\mathrm{Ar}}\right), 8.02(\mathrm{~s}, 1 \mathrm{H}, \mathrm{NH}), 7.38-7.29\left(\mathrm{~m}, 2 \mathrm{H}, \mathrm{H}_{\mathrm{Ar}}\right), 7.04\left(\mathrm{~d}, J=5.2 \mathrm{~Hz}, 1 \mathrm{H}, \mathrm{H}_{\mathrm{Ar}}\right), 6.93-6.84\left(\mathrm{~m}, 2 \mathrm{H}, \mathrm{H}_{\mathrm{Ar}}\right), 4.56$ $\left(\mathrm{d}, J=6.2 \mathrm{~Hz}, 2 \mathrm{H}, \mathrm{CH}_{2}\right), 3.74\left(\mathrm{~s}, 3 \mathrm{H}, \mathrm{CH}_{3}\right) .{ }^{13} \mathrm{C}$ NMR $\left(101 \mathrm{MHz}, \mathrm{DMSO}-d_{6}\right) \delta 163.3,162.8,162.3,158.6$, 145.3, 132.1, 129.4, 128.9, 114.1, 97.3, 55.5, 44.0. HRMS-ESI $(m / z)$ : calcd for $\mathrm{C}_{14} \mathrm{H}_{13} \mathrm{~N}_{7} \mathrm{NaO}_{3}[\mathrm{M}+\mathrm{Na}]$ : 350.0972; found: 350.0973 .

$N$-(4-Methoxyphenyl)-4-(3-nitro-1H-1,2,4-triazol-1-yl)pyrimidin-2-amine (2e)

A glass screw-capped vial containing a magnetic stir bar was charged with 2-chloro-4-(3-nitro-1H1,2,4-triazol-1-yl)pyrimidine (5, $0.44 \mathrm{mmol}, 100 \mathrm{mg})$, 4-methoxyaniline (1.32 mmol, $163 \mathrm{mg}$ ) and DMSO $(2 \mathrm{~mL})$. The reaction mixture was stirred at $100{ }^{\circ} \mathrm{C}$ for $3 \mathrm{~h}$. The reaction mixture was poured into water $(10 \mathrm{~mL})$ and cooled in a refrigerator. The resulting precipitate was filtered off and additionally crystallized from $96 \%$ ethanol to afford the title compound. Orange solid, yield $41 \%$; mp $236-238^{\circ} \mathrm{C}$ (decomp.). ${ }^{1} \mathrm{H}$ NMR (500 MHz, DMSO- $\left.d_{6}\right) \delta 9.71(\mathrm{~s}, 1 \mathrm{H}, \mathrm{NH}), 9.46(\mathrm{~s}, 1 \mathrm{H}$, triazole), $8.70(\mathrm{~d}, J=5.2 \mathrm{~Hz}$, $\left.1 \mathrm{H}, \mathrm{H}_{\mathrm{Ar}}\right), 7.74-7.59\left(\mathrm{~m}, 2 \mathrm{H}, \mathrm{H}_{\mathrm{Ar}}\right), 7.23\left(\mathrm{~d}, J=5.2 \mathrm{~Hz}, 1 \mathrm{H}, \mathrm{H}_{\mathrm{Ar}}\right), 7.04-6.87\left(\mathrm{~m}, 2 \mathrm{H}, \mathrm{H}_{\mathrm{Ar}}\right), 3.78\left(\mathrm{~s}, 3 \mathrm{H}, \mathrm{CH}_{3}\right)$. ${ }^{13} \mathrm{C}$ NMR (101 MHz, DMSO- $\left.d_{6}\right) \delta 163.3,162.7,160.0,155.4,154.9,145.4,132.8,121.8,114.4,99.6,55.6$. HRMS-ESI $(\mathrm{m} / \mathrm{z})$ : calcd for $\mathrm{C}_{13} \mathrm{H}_{11} \mathrm{~N}_{7} \mathrm{O}_{3} \mathrm{Ag}$ [M + Ag]: 419.9969, 421.9966; found: 419.9987, 421.9984. 
4-(3-Nitro-1H-1,2,4-triazol-1-yl)-N-(p-tolyl)pyrimidin-2-amine (2m)

A glass screw-capped vial containing a magnetic stir bar was charged with 2-chloro-4-(3-nitro- $1 \mathrm{H}$ 1,2,4-triazol-1-yl)pyrimidine (5, $0.44 \mathrm{mmol}, 100 \mathrm{mg}), p$-toluidine $(1.32 \mathrm{mmol}, 142 \mathrm{mg})$ and DMSO (2 mL). The reaction mixture was stirred at $100{ }^{\circ} \mathrm{C}$ for $3 \mathrm{~h}$. The reaction mixture was poured into water $(10 \mathrm{~mL})$ and cooled in a refrigerator. The resulting precipitate was filtered off and additionally crystallized from ethanol to afford the title compound. Orange solid, yield $62 \%$; mp $229-231{ }^{\circ} \mathrm{C}$ (decomp.). ${ }^{1} \mathrm{H} \mathrm{NMR}$ $\left(400 \mathrm{MHz}, \mathrm{DMSO}-d_{6}\right) \delta 9.78(\mathrm{~s}, 1 \mathrm{H}, \mathrm{NH}), 9.47\left(\mathrm{~s}, 1 \mathrm{H}\right.$, triazole), $8.73\left(\mathrm{~d}, J=5.2 \mathrm{~Hz}, 1 \mathrm{H}, \mathrm{H}_{\mathrm{Ar}}\right), 7.68-7.59$ $\left(\mathrm{m}, 2 \mathrm{H}, \mathrm{H}_{\mathrm{Ar}}\right), 7.26\left(\mathrm{~d}, J=5.2 \mathrm{~Hz}, 1 \mathrm{H}, \mathrm{H}_{\mathrm{Ar}}\right), 7.17\left(\mathrm{~d}, J=8.1 \mathrm{~Hz}, 2 \mathrm{H}, \mathrm{H}_{\mathrm{Ar}}\right), 2.31\left(\mathrm{~s}, 3 \mathrm{H}, \mathrm{CH}_{3}\right) .{ }^{13} \mathrm{C}$ NMR (101 MHz, DMSO) $\delta 163.3,162.6,159.9,154.9,145.4,137.2,131.8,129.6,120.1,99.9,20.9$. HRMS-ESI $(\mathrm{m} / \mathrm{z})$ : calcd for $\mathrm{C}_{13} \mathrm{H}_{11} \mathrm{~N}_{7} \mathrm{NaO}_{2}$ [M + Na]: 320.0866; found: 320.0876 .

\subsection{Evaluation of Antimycobacterial Activity}

Mycobacterium tuberculosis $\mathrm{H}_{37} \mathrm{Rv}$ strain was obtained from the Federal Scientific Center for Expertise of Medical Products (RF Ministry of Health Care) on 7 August 2013 (origin: Prague, Institute of Hygiene and Epidemiology, 1976). The lyophilized strain was seeded on Löwenstein-Jensen growth medium. The 21-days culture was suspended in physiological solution containing glycerol $(15 \%)$ and transferred into cryotubes to be stored at $-80^{\circ} \mathrm{C}$. Prior to the experiment ( 3 weeks), the culture was brought to ambient temperature and re-seeded into Löwenstein-Jensen growth medium. Thus, the second generation of the original M. tuberculosis culture was used in this study.

REMA (resazurin microtitre plate assay) [23] was used to determine the activity of the synthesized compounds. A 3-week M. tuberculosis culture was transferred into a dry, sterile tube containing 8-9 $3 \mathrm{~mm}$ glass beads. The tube was placed on a Vortex shaker for 30-40 s, followed by addition of Middlebrook 7H9 Broth (5 mL; Becton Dickinson, Franklin Lakes, NJ, USA; catalogue No. 271310). The turbidity of the bacterial suspension was adjusted to $1.0 \mathrm{McFarland}$ units (corresponding to approximately $3 \times 10^{8}$ bacteria/mL) and diluted 20-fold with Middlebrook 7H9 Broth containing OADC enrichment (Becton Dickinson, Franklin Lakes, NJ, USA; catalogue No. 245116). The same culture medium was used to prepare the 1:100 M. tuberculosis (1\% population) control. The concentration of stock solutions of the compounds in DMSO $(10 \mathrm{mg} / \mathrm{mL})$ was adjusted to $800 \mu \mathrm{g} / \mathrm{mL}$ by dilution with Middlebrook 7H9 Broth (containing OADC enrichment). A $200 \mu \mathrm{L}$ aliquot of this solution was introduced into the 2nd row of a 96-well microtitre plate. This row was used to perform 2-fold serial dilutions using and 8-channel pipette to obtain final concentrations of 1.6, 3.1, 6.2, 12.5, 25, 50, 100, 200 and $400 \mu \mathrm{g} / \mathrm{mL}$ of the compound in rows 2-9 (accounting for $100 \mu \mathrm{L}$ of bacterial suspension introduced for testing). Row 10-MTb suspension control, row 11-same culture diluted 10-fold (the $1 \%$ control). Row 12 was used as a blank control for optical density reading ( $200 \mu \mathrm{L}$ of the grown medium). The bacterial suspension $(100 \mu \mathrm{L})$ was introduced into each well except rows 11 (1\% population control) and 12 (blank culture medium), to the total volume of $200 \mu \mathrm{L}$ in each well. The plates were incubated at $35^{\circ} \mathrm{C}$ for 7 days, followed by addition of $0.01 \%$ aqueous solution $(30 \mu \mathrm{L})$ of resazurin (Sigma, St. Louis, MO, USA; product No. R7017) in each well and the further incubation for $18 \mathrm{~h}$ at $35^{\circ} \mathrm{C}$. The fluorescence reading was performed using the FLUOstar Optima plate reader operating at $\lambda_{\mathrm{ex}}=520 \mathrm{~nm}$ and $\lambda_{\mathrm{em}}=590 \mathrm{~nm}$. By comparing the mean values ( $\pm \mathrm{SD}$ at $\left.p=0.05\right)$ of fluorescence in the control wells (row 12, blank and row 11, 1\% control) and the wells containing the compound tested, the bacterial viability was determined.

\subsection{Screening against ESKAPE Pathogens}

Susceptibility testing of the following microorganisms: Enterococcus faecium, Staphylococcus aureus, Klebsiella pneumoniae, Acinetobacter baumannii, Pseudomonas aeruginosa and Enterobacter aerogenes, to compounds 1a-s, 2a-s and $\mathbf{4}$ as well as ciprofloxacin (positive control) was performed using the conventional Kirby-Bauer disk diffusion test [24] under the Standard Operating Procedure of The European Committee on Antimicrobial Susceptibility Testing (EUCAST) [25]. Disks containing 
$5 \mathrm{mg}$ of ciprofloxacin were used. Solutions of compounds 1a-s, 2a-s and 4 in dimethyl sulfoxide $(1 \mathrm{mg} / 10 \mathrm{~mL})$ were prepared and diluted to a volume of $1 \mathrm{~mL}$ with deionized water. The resulting solutions aliquots $(5 \mathrm{~mL})$ were added to a Petri dish containing Muller-Hilton agar inoculated with a bacterial suspension (McFarland OD 1/4 0.5). After drying of the compound solution, the Petri dish was incubated at $37^{\circ} \mathrm{C}$ for $18 \mathrm{~h}$. By measuring the bacterial growth inhibition zone diameter around the disc with ciprofloxacin or the compounds' dried solution circular spot, the susceptibility to a drug was assessed. Additionally, minimum inhibitory concentrations (MIC, $\mu \mathrm{g} / \mathrm{mL}$ ) were determined using serial broth dilutions [26].

\subsection{Cyclic Voltammetry}

Cyclic voltammetry studies were performed with the potential scan rate of $100 \mathrm{mV} \cdot \mathrm{s}^{-1}$ in a sealed three-electrode cell at $25^{\circ} \mathrm{C}$ under argon atmosphere. A flow of argon (extra-purity grade, $99.998 \%$ ) was bubbled through the solutions to remove dissolved oxygen. Electrochemical measurements were performed in $10^{-3} \mathrm{~mol} \cdot \mathrm{dm}^{-3}$ solutions of the tested compounds in $0.1 \mathrm{M} \mathrm{TBAClO}_{4} / \mathrm{DMF}$. A typical cell used consisted of a working electrode (glassy carbon disk, $0.07 \mathrm{~cm}^{2}$ ), a counter electrode (platinum plate, $1 \mathrm{~cm}^{2}$ ) and a reference electrode (BAS MF-2062 Ag/0.1 $\mathrm{M} \mathrm{AgNO}_{3}$ solution in $\mathrm{CH}_{3} \mathrm{CN}$, calibrated by $10^{-3} \mathrm{~mol} \cdot \mathrm{dm}^{-3}$ ferrocene external standard as a pseudo-reference electrode to comprise $-188 \mathrm{mV}$ referred to $\mathrm{Fc} / \mathrm{Fc}^{+}$). All potentials are quoted versus the above reference electrode.

Supplementary Materials: The following are available online at http://www.mdpi.com/2079-6382/9/10/666/s1, Table S1: Crystal data and structure refinement for 1e, 5; Table S2: Crystal data and structure refinement for 2o, 2k; Table S3: Crystal data and structure refinement for $\mathbf{2 n}, \mathbf{2 h}$; Copies of ${ }^{1} \mathrm{H}$ and ${ }^{13} \mathrm{C}$ NMR spectra.

Author Contributions: Organic synthesis, S.C. and D.D.; screening against ESKAPE pathogens, E.R., L.K.; electrochemical studies, O.L.; evaluation of antimycobacterial activity, O.M., M.D., T.V.; data curation, writing-review and editing, O.B.; conceptualization, project administration, writing-original draft preparation, M.K. All authors have read and agreed to the published version of the manuscript.

Funding: This research was supported by the Russian Federation Government Megagrant 14.W03.031.0025.

Acknowledgments: We thank the Research Centre for Magnetic Resonance, the Center for Chemical Analysis and Materials Research and the Centre for X-ray Diffraction Methods of Saint Petersburg State University Research Park for obtaining the analytical data.

Conflicts of Interest: The authors declare no conflict of interest. The funders had no role in the design of the study; in the collection, analyses, or interpretation of data; in the writing of the manuscript, or in the decision to publish the results.

\section{References}

1. Watanabe, Y.; Arimori, S. Preparation of tetrazolinone derivatives as agrochemical fungicides and pesticides. Chem. Abstr. 2015, 162, 418609.

2. Jones, R.G.; Terando, N.H. Antibacterial compositions containing 3-nitropyrazoles. Chem. Abstr. 1978, 88, 152614.

3. Srinivas, D.; Ghule, V.D.; Tewari, S.P.; Muralidharan, K. Synthesis of Amino, Azido, Nitro, and Nitrogen-Rich Azole-Substituted Derivatives of $1 H$-Benzotriazole for High-Energy Materials Applications. Chem. Eur. J. 2012, 18, 15031. [CrossRef] [PubMed]

4. Kommu, N.; Ghule, V.D.; Kumar, A.S.; Sahoo, A.K. Triazole-Substituted Nitroarene Derivatives: Synthesis, Characterization, and Energetic Studies. Chem. Asian J. 2014, 9, 166. [CrossRef] [PubMed]

5. Duddu, R.; Dave, P.R.; Damavarapu, R.; Surapaneni, R.; Parrish, D. Nucleophilic Substitution Reactions of 1-Methyl-2,4,5-trinitroimidazole (MTNI). Synth. Commun. 2009, 39, 4282. [CrossRef]

6. Chuprun, S.S.; Kantin, G.; Krasavin, M. Synthesis and Medicinal Applications of N-Aryl-C-nitroazoles. Mini Rev. Med. Chem. 2018, 18, 1733. [CrossRef] [PubMed]

7. Olive, P.L. Correlation between the half-wave reduction potentials of nitroheterocycles and their mutagenicity in Chinese hamster V79 spheroids. Mutat. Res. Fundam. Mol. Mech. Mutagen. 1981, 82, 137. [CrossRef] 
8. Krasavin, M.; Parchinsky, V.; Kantin, G.; Manicheva, O.; Dogonadze, M.; Vinogradova, T.; Karge, B.; Brönstrup, M. New nitrofurans amenable by isocyanide multicomponent chemistry are active against multidrug-resistant and poly-resistant Mycobacterium tuberculosis. Bioorg. Med. Chem. 2017, 25, 1867. [CrossRef]

9. Krasavin, M.; Lukin, A.; Vedekhina, T.; Manicheva, O.; Dogonadze, M.; Vinogradova, T.; Zabolotnykh, N.; Rogacheva, E.; Kraeva, L.; Sharoyko, V.; et al. Attachment of a 5-nitrofuroyl moiety to spirocyclic piperidines produces non-toxic nitrofurans that are efficacious in vitro against multidrug-resistant Mycobacterium tuberculosis. Eur. J. Med. Chem. 2019, 166, 125. [CrossRef]

10. Krasavin, M.; Lukin, A.; Vedekhina, T.; Manicheva, O.; Dogonadze, M.; Vinogradova, T.; Zabolotnykh, N.; Rogacheva, E.; Kraeva, L.; Yablonsky, P. Conjugation of a 5-nitrofuran-2-oyl moiety to aminoalkylimidazoles produces non-toxic nitrofurans that are efficacious in vitro and in vivo against multidrug-resistant Mycobacterium tuberculosis. Eur. J. Med. Chem. 2018, 157, 1115. [CrossRef]

11. Matsumoto, M.; Hashizume, H.; Tomishige, T.; Kawasaki, M.; Tsubouchi, H.; Sasaki, H.; Shimokawa, Y.; Komatsu, M. OPC-67683, a Nitro-Dihydro-Imidazooxazole Derivative with Promising Action against Tuberculosis In Vitro and In Mice. PLoS Med. 2006, 3, 2131. [CrossRef] [PubMed]

12. Stover, C.K.; Warrener, P.; VanDevanter, D.R.; Sherman, D.R.; Arain, T.M.; Langhorne, M.H.; Anderson, S.W.; Towell, J.A.; Yuan, Y.; McMurray, D.N.; et al. A small-molecule nitroimidazopyran drug candidate for the treatment of tuberculosis. Nature 2000, 405, 962. [CrossRef] [PubMed]

13. Nepali, K.; Lee, H.-Y.; Liou, J.-P. Nitro-Group-Containing Drugs. J. Med. Chem. 2019, 62, 2851. [CrossRef] [PubMed]

14. Krasavin, M.; Trifonov, R.E.; Tolstyakov, V.V.; Dar'in, D.V.; Vinogradova, T.I.; Manicheva, O.A.; Dogonadze, M.Z.; Zabolotnykh, N.V.; Vitovskaya, M.L.; Yablonskii, P.K. 5-Methyl-7-(3-nitro-[1,2,4]triazol1-yl)-[1,2,4]triazolo[1,5-a]pyrimidine, having anti-tuberculosis activity against the agent with multiple drug resistance, and a method for production thereof. Chem. Abstr. 2019, 171, 563769.

15. Pendleton, J.N.; Gorman, S.P.; Gilmore, B.F. Clinical relevance of the ESKAPE pathogens. Expert Rev. Anti Infect. Ther. 2013, 11, 297. [CrossRef] [PubMed]

16. Papadopoulou, M.V.; Bloomer, W.D.; Rosenzweig, H.S.; Wilkinson, S.R.; Szular, J.; Kaiser, M. Nitrotriazole-based acetamides and propanamides with broad spectrum antitrypanosomal activity. Eur. J. Med. Chem. 2016, 123, 895. [CrossRef]

17. Lagoja, I.M.; Pochet, S.; Boudou, V.; Little, R.; Lescrinier, E.; Rozenski, J.; Herdewijn, P. A Short Path Synthesis of $\left[{ }^{13} \mathrm{C} /{ }^{15} \mathrm{~N}\right]$ Multilabeled Pyrimidine Nucleosides Starting from Glucopyranose Nucleosides. J. Org. Chem. 2003, 68, 1867. [CrossRef]

18. Goldstein, B.P.; Vidal-Plana, R.R.; Cavalleri, B.; Zerilli, L.; Carniti, G.; Silvestri, L.G. The Mechanism of Action of Nitro-heterocyclic Antimicrobial Drugs. Metabolic Activation by Micro-organisms. J. Gen. Microbiol. 1977, 100, 283. [CrossRef]

19. Edwards, D.I.J. Nitroimidazole drugs-action and resistance mechanisms I. Mechanism of action. Antimicrob. Chemother. 1993, 31, 9. [CrossRef]

20. Olender, D.; Zwawiak, J.; Zaprutko, L. Multidirectional Efficacy of Biologically Active Nitro Compounds Included in Medicines. Pharmaceuticals 2018, 11, 54. [CrossRef]

21. Paula, F.R.; Trossini, G.H.; Ferreira, E.I.; Serrano, S.H.P.; Menezes, C.M.S.; Tavares, L.C. Theoretical and voltammetric studies of 5-nitro-heterocyclic derivatives with potential trypanocidal activities. J. Braz. Chem. Soc. 2010, 21, 740. [CrossRef]

22. Haeili, M.; Moore, C.; Davis, C.; Cochran, J.; Shah, S.; Shrestha, T.; Zhang, Y.; Bossmann, S.; Benjamin, W.; Kutsch, O.; et al. Copper Complexation Screen Reveals Compounds with Potent Antibiotic Properties against Methicillin-Resistant Staphylococcus aureus. Antimicrob. Agents Chemother. 2014, 58, 3727. [CrossRef] [PubMed]

23. Martin, A.; Camacho, M.; Portaels, F.; Palomino, C.C. Resazurin microtiter assay plate testing of Mycobacterium tuberculosis susceptibilities to second-line drugs: Rapid, simple, and inexpensive method. Antimicrob. Agents Chemother. 2003, 47, 3616. [CrossRef] [PubMed]

24. Bauer, A.W.; Kirby, W.M.; Sherris, J.C.; Turck, M. Antibiotic Susceptibility Testing by a Standardized Single Disk Method. Am. J. Clin. Pathol. 1966, 45, 493. [CrossRef] 
25. Standard Operating Procedure: Procedure for Establishing Zone Diameter Breakpoints and Quality Control Criteria for New Antimicrobial Agents. EUCAST SOP 9.1. 2018. Available online: https://www.eucast.org/fileadmin/src/media/PDFs/EUCAST_files/EUCAST_SOPs/2018/EUCAST _SOP_9.1_Disk_diffusion_breakpoints_and_QC_ranges_20180123.pdf (accessed on 23 January 2018).

26. Wiegand, I.; Hilpert, K.; Hancock, R.E. Agar and broth dilution methods to determine the minimal inhibitory concentration (MIC) of antimicrobial substances. Nat. Protoc. 2008, 3, 163. [CrossRef]

(C) 2020 by the authors. Licensee MDPI, Basel, Switzerland. This article is an open access article distributed under the terms and conditions of the Creative Commons Attribution (CC BY) license (http://creativecommons.org/licenses/by/4.0/). 